\title{
DIAGNOSTICKÁ BATERIE KOGNITIVNÍCH PROCESŮ (CAS2) Recenze metody
}

Autor RECEnzE: MARTin PÍRKo

Filozofická fakulta Masarykovy univerzity ${ }^{1}$

\begin{tabular}{|c|l|}
\hline \multicolumn{1}{|c|}{ datum vzniku recenze: } & 24. 12.2017 \\
\hline 1.1 název nástroje: & Diagnostická baterie kognitivních procesů, druhé vydání \\
\hline \multicolumn{1}{|c|}{ zkrácený název: } & CAS2 \\
\hline 1.2 původní název: & Cognitive Assessment System \\
\hline 1.4 autoři původního testu: & Jack A. Naglieri, Jagannath P. Das, Sam Goldstein \\
\hline 1.3 autoři lokální adaptace: & Lenka Krejčová \\
\hline 1.7 lokální distributor: & Propsyco, s.r.o. \\
\hline $1.9 .1 / 1.9 .2$ datum vydání: & 2017 \\
\hline
\end{tabular}

\section{Obecné informace}

Diagnostická baterie kognitivních procesů (Cognitive Assessment System), druhé vydání, (dále ve zkratce CAS2) představuje soubor individuálně administrovaných psychodiagnostických metod, který má za úkol zjistit úroveň neurokognitivních procesů (Plánování, Pozornost, Následné a Simultánní procesy) dětí, dospívajících a mladých dospělých od 5 do 18 let včetně.

CAS2 navazuje na inteligenční teorii kognitivního zpracování PASS, kterou vytvořila trojice amerických autorů Das, Naglieri a Kirby (1994) a která vychází z poznatků ruského neuropsychologa Alexandra Luriji (1973) o modularitě a vzájemné propojenosti mozku a o třech základních funkčních jednotkách kognitivních procesů. Das, Naglieri a Kirby (1994) tento základ postupně přetvořili v model čtyř základních procesů práce s informacemi a řešení problémů PASS: $\mathrm{P}$ (planning) = plánování, $\mathrm{A}$ (attention) = pozornost, $\mathrm{S}$ (simultaneous) = simultánní zpracování, $\mathrm{S}$ (successive) = následné zpracování. Tento model slouží dle autorů k tomu, aby nám pomohl porozumět povaze

\footnotetext{
${ }^{1}$ Psychologický ústav, Filozofická fakulta Masarykovy univerzity, Arne Nováka 1, 60200 Brno Doručeno do redakce: 28 . prosince 2017.
} 
individuálních rozdílů, aby nám poskytl rámec pro vyšetření a aby nás vedl přímo $\mathrm{k}$ podpoře založené na teorii.

Čtyři základní procesy jsou v rámci teorie popsány následovně. Plánování (měřeno subtesty Plánované kódování, Plánované spojení, Plánované párování čísel) se používá k rozhodování, sebepozorování, autokorekci, k řízení myšlenek a činností. Pozornost (Expresivní pozornost, Hledání čísel, Receptivní pozornost) je využívána pro selektivní soustředění na určitý podnět a zároveň k potlačování reakcí na podněty jiné. Simultánní zpracování (Matrice, Verbálně-prostorové vztahy, Figurální pamět') spojuje oddělené podněty do jednoho celku, a to jak neverbálně-prostorové, tak verbálně-gramatické. Následné zpracování (Slovní řady, Opakování vět/Otázky, Opakování viděných čísel) integruje informace do určitého lineárního sledu a umožňuje například porozumět významu vyprávění.

Test CAS2 se skládá celkem ze 13 subtestů, které mohou složit bud’ základní (8 subtestů) nebo rozšířenou (12 subtestů) baterii (dva ze subtestů se alternují podle věku probanda). V rozšířené baterii najdeme navíc subtesty Plánované párování čísel, Figurální pamět', Receptivní pozornost a Opakování viděných čísel. Subtesty jsou zjevně inspirovány některými jinými známými psychodiagnostickými metodami (Test cesty, Stroopův test, Ravenovy progresivní matice, testy pozornosti atd.). Administrace trvá přibližně 60 minut (základní) nebo 90 minut (rozšířená baterie). Testování probíhá formou tužka-papír, př́padně rozhovorem. Výsledkem metody je soubor vážených skóru jednotlivých subtestů, které skládají čtyři škálové skóry základních procesů dle teorie PASS. K dispozici je i celková škála kognitivních procesů (podobná inteligenci), ale kromě ní i odvozené skóry exekutivních funkcí a pracovní paměti.

Autoři původní verze metody uvádí v technickém a interpretačním manuálu metody, že prezentovaný test nabízí multidimenzionální úplné hodnocení základních neurokognitivních schopností přesahujících obecnou inteligenci. Dále tvrdí, že test odhaluje specifické kognitivní problémy související s konkrétními studijními neúspěchy, je navrhováno užití pro rozlišení ADHD, poruch učení a mentální retardace, traumatického poranění mozku, vážných emočních poruch a nadání, je relevantní pro intervenci, správně diagnostikuje jednotlivce ze znevýhodněných skupin a funguje napříč kulturami a zvyky. Autoři nabízí v návaznosti na vyšetření CAS2 v USA komerční intervenční programy zaměřené na kognitivní obohacení COGENT a PREP. Autoři lokální verze vyjádřili $\mathrm{v}$ předmluvě $\mathrm{k}$ Administrativnímu a skórovacímu manuálu přání, aby materiály dostupné $\mathrm{v}$ anglickém jazyce vedoucí od testování k intervenci (Pomoc dětem s učením - druhé vydání) byly rovněž přeloženy do češtiny.

\section{Předpoklady použití}

Z povahy testu je zjevné, že je potřebná řízená individuální administrace. Pro zakoupení testu je nutná licence $C$ vydavatele Propsyco, což znamená, že kupující musí prokázat absolutorium magisterského studia psychologie (Propsyco, 2017b). Vydavatel však nabízí 
další vzdělání týkající se metody a na svých webových stránkách připojuje odkaz na zaškolení pořádané pražským Dys-centrem (Propsyco, 2017a).

Autoři správně varují před možnými riziky chybné interpretace výsledků metody. Uvádějí, že by se měly výsledky metody interpretovat $\mathrm{v}$ souladu s manuály $\mathrm{k}$ testu a obecnými standardy pro užívání a interpretaci testů (viz na toto téma např. Ježek, 2010). V manuálu se dále píše, že výsledky CAS2 by měly být interpretovány pouze odborníky s odpovídajícím proškolením a zkušenostmi. Absolvování výše zmíněného kurzu sice není nutné, avšak distributor testu jej důrazně doporučuje, aby byla minimalizována možná rizika v interpretaci výsledků. Případné proškolení je tedy zodpovědností př́íslušného uživatele testu (J. Laciga, osobní komunikace, 28. ledna 2018).

\section{Administrace a skórování}

CAS2 představuje na první pohled velice dobře vytvořenou baterii prrátelskou $\mathrm{k}$ administrátorovi i k probandovi. Manuály, podnětové sešity a všechny další součásti testu jsou přehledné, jasně strukturované a podávají zřejmé návody, jak test administrovat a vyhodnocovat. V záznamovém sešitu najde uživatel metody správné odpovědi hned k sedmi subtestům (Matrice, Verbálně-prostorové vztahy, Expresivní pozornost, Slovní řady, Opakování vět, Otázky, Opakování viděných čísel). Ke čtyřem rychlostním subtestům (Plánované kódování, Plánované párování čísel, Hledání čísel, Receptivní pozornost) jsou k dispozici poloprůhledné skórovací šablony a pro vyhodnocení subtestu Plánované spojení stačí uživateli testu stopky. Trochu komplikovanější je vyhodnocení (i administrace) subtestu Figurální pamět', ve kterém je probandovým úkolem tužkou obtahovat prezentované tvary ve složitějších útvarech. Manuál vám i zde zjednoduší situaci obrázky toho, co má proband obtáhnout, z pohledu administrátora. Dále se už pracuje s převodními tabulkami, kdy z poměrových skórů získáte hrubé skóry a $\mathrm{z}$ hrubých skórů vážené skóry. Vše je opět dobře vysvětleno v manuálu. Velkou časovou náročnost tohoto procesu by jistě snížila nějaká automatizační aplikace, pro anglickou verzi testu je k dispozici, u nás bohužel nikoliv.

Převodními tabulkami s věkovými normami tak tedy $\mathrm{z}$ hrubých skórů jednotlivých subtestů vytvoříte vážené skóry s průměrem 10 a standardní odchylkou 3. Ty se př́́slušně sečtou do čtyř škálových skórů a jednoho celkového skóru. Kromě nich můžete subtesty sečíst také do vedlejších skórů exekutivních funkcí, pracovní paměti, verbálního obsahu a neverbálního obsahu. Součty skórů se pak převedou pomocí tabulek na standardní skóry s průměrem 100 a standardní odchylkou 15. Samožrejmě jsou k dispozici převodní tabulky pro základní i rozširrenou baterii, v nichž nechybí ani percentilové vyjádření výsledku vůči standardizačnímu souboru a příslušné intervaly spolehlivosti. Ze získaných údajů lze vypracovat přehledný grafický profil standardních skórů a škálových skórů ne nepodobný tomu, na co je český uživatel zvyklý u jiných kognitivních testů (např. WISC-III). 
Velkou přidanou hodnotou testu CAS2 je zahrnutí statistického srovnání škálových a standardních skórů na úrovni jednoho probanda (ipsativní srovnání) a to jak u rozšířené, tak u základní baterie. Jinými slovy test nabízí statistický základ pro identifikaci silných a slabých stránek každého jednoho probanda. Ve vztahu k průměru standardních skórů PASS můžete pomocí rozdílů jednotlivých standardních skórů nalézt v tabulkách Interpretačního a technického manuálu, zda je tento rozdíl významný (na hladině významnosti 0,05 nebo 0,10 ) a jak moc byl tento a vyšší rozdíl zastoupen ve standardizačním vzorku (údaj v procentech). Obdobně lze zjistit významnost odchylek škálových skóru jednotlivých subtestů vzhledem ke čtyřem základním procesům PASS.

Kromě toho CAS2 umožňuje vypočítat doplňkové kombinované skóry (Exekutivní funkce s pracovní pamětí, Exekutivní funkce bez pracovní paměti, Pracovní pamět', Verbální obsah, Neverbální obsah) a nabízí srovnání případných dvou administrací testu u jednoho probanda. V subtestech Slovní řady a Opakování viděných čísel pak umožňuje srovnat výkon probanda ve dvou oblastech stejné kognitivní schopnosti za použití zvukových a zrakových podnětů. CAS2 navíc vybízí ke kvalitativnímu hodnocení strategií užitých probandem v subtestech procesu Plánování.

\section{Vývoj škál}

$\mathrm{K}$ vývoji testu se autoři testu vyjadřují pouze velice stručně v souvislosti s reakcí na recenze původního CAS. Jako nejvýraznější plus uvádí na prvním místě získání dat od standardizačního vzorku, který dobře reprezentuje nejaktuálnější údaje sčítání lidu v USA. Krom přidání položek do všech subtestů přibyl celý jeden nový subtest a jeden subtest byl vyměněn. Došlo i k úpravě obsahu, délky a doby administrace některých položek za účelem posílení faktorové struktury, kterou v př́ípadě původního CAS velice výstižně kritizovali Kranzler a Keith (1999). Významně více se o vývoji škál bohužel nedozvíme.

\section{Technické parametry}

\section{Reliabilita}

Autoři české standardizace se při hodnocení reliability opírají o zjištění týkající se anglické verze metody. Ta skutečně dobře dokumentuje reliabilitu jako vnitřní konzistenci i test-retest reliabilitu. Koeficienty alfa byly vUSA spočteny ze standardizačního vzorku pro jednotlivé subtesty a věkové skupiny a jejich hodnoty se pohybují v rozmezí $0,80-0,97$, což představuje přesvědčivý důkaz o vysoké vnitřní konzistenci testu. Test-retest reliabilita byla v USA zkoumána na vzorku 144 studentů, přičemž probandi byli znovu testování po 19 dnech. Výsledné koeficienty reliability jsou slabší, ale stále velice uspokojivé $(0,75-0,94)$. Kromě toho američtí autoři testu též zkoumali shodu (autoři používají slovo „konzistence“) hodnotitelů, kdy dva zaměstnanci vydavatele testu hodnotili 50 protokolů CAS2. Shoda hodnotitelů dosahovala výborných hodnot $(0,97-0,99)$. 
V české standardizaci nám chybí alespoň průzkum reliability jako vnitřní konzistence na českém standardizačním vzorku. Takto se celé hodnocení reliability bohužel opírá pouze o výzkumy týkající se anglické verze testu. Není zcela jasné, na základě kterých odhadů reliability jsou pak v manuálu metody vypočítávány standardní chyby měření a intervaly spolehlivosti, autoři české verze toto nijak nekomentují.

\section{Validita}

Česká adaptace metody vychází z výzkumů validity provedené na americké verzi testu. K nim pak připojují dvě vlastní studie na malých vzorcích, které popíšeme níže. Konstruktovou validitu původní autoři nejprve zkoumají srovnáním s původním testem CAS, zkrácenou verzí CAS2: Brief, posuzovacími škálami CAS2: Rating Scale a řadou metod měřících příbuzné konstrukty (WISC-IV, CTONI-2, PTONI, WJ-III, TOSCRF-2, GORT-5, CMAT, WRAT-4). Korelace s příbuznými metodami jsou podle očekávání vysoké (CAS $r=0,88$, CAS: Brief $r=0,8$, CAS: Rating Scale $r=0,75$ ) a i s dalšími metodami jsou velice uspokojivé. Českého čtenáře bude asi nejvíce zajímat korelace s WISC-IV $(r=0,77)$ a s WJ-III $(r=0,62)$. Korelační studie jsou ovšem provedené na relativně malých vzorcích (např. u WISC-IV $N=35$, u WJ-III $N=36$ ) a jejich platnost je navíc omezena i specifickými populacemi, které byly výzkumu podrobeny (např. u WISC-IV i WJ-III se jednalo hlavně o děti s ADHD a poruchami chování). Je také nejasné, do jaké míry jsou konstrukty měřené pomocí CAS2 př́ibuzné s konstrukty měřenými srovnávanými testy.

Poměrně silný důkaz validity testu však poskytuje hlubší analýza standardizačního souboru, kde autoři původní verze testu hledají rozdíly mezi skupinami podle věku, pohlaví, rasy a etnické př́íslušnosti. Rozdíly odpovídají očekávání, např. výkon prakticky ve všech subtestech koreluje pozitivně s věkem. Autoři dále například zjistili, že probandi identifikovaní jako „nadaní a talentovaní“ mají významně vyšší průměrný celkový skór (o 11,8 bodů) a že probandi u nichž byl diagnostikován syndrom ADHD získali nízké skóry ve škálách Pozornost a Plánování.

Autoři původního testu také na standardizačním souboru provedli konfirmační faktorovou analýzu, kde zkoumali celkem 4 modely ve 4 věkových skupinách. Předpokládaný čtyřfaktorový model odpovídá pozorovaným datům nejlépe $\left(\chi^{2} / d f=\right.$ 2,1-3,2; RMSEA = 0,057-0,102). Jak ovšem správně poznamenává ve své recenzi McGill (2015), autoři v manuálu ve všech ostatních částech pracují s hierarchickým modelem, kdy by měla druhá Lurijova funkční jednotka v sobě zahrnovat simultánní a následné procesy, ten však konfirmační faktorovou analýzou vůbec netestují. Odchylují se od něj k jednoduchému čtyřfaktorovému modelu bez nějakého hlubšího komentáře. Také není jasné, jak se autoři testu vyrovnali s kritikou původní verze CAS Kranzlera a Keitha (1999), kteří pro standardizační data nalézají přiléhavější faktorové řešení odporující teorii PASS. To, že jejich kritika může být oprávněná, dokumentují skóry RMSEA, které jsou pod přijatelnou hodnotou 0,06 (Hu \& Bentler, 1999) pouze u čtyřfaktorového modelu testovaného na datech dětí ve věku 8-10 let. 
Posledním argumentem původních autorů pro validitu metody je analýza provedená opět na standardizačním souboru. Autoři předpokládali, že probandi používající konkrétní strategie v subtestech Plánování (bud' pozorované administrátorem anebo zmíněné v inquiry) budou významně lépe skórovat ve škále Plánování. Tento předpoklad se potvrdil, ovšem výsledná velikost efektu byla zanedbatelná (Cohenovo $d=0,06-0,19$ ). Dokonce vsubtestu Plánované spojení byl efekt opačný, než autoři předpokládali (Cohenovo $d=-0,03$ ).

V ČR byly provedeny dvě malé validizační studie. V první z nich výzkumníci srovnávali dvojicí testů 20 probandů se specifickými poruchami učení. $10 \mathrm{z}$ nich testovali pomocí CAS2 a WISC-III a dalších 10 pomocí CAS2 a K-ABC. Zjistilo se, že metody spolu středně silně korelují (s WISC-III $r=0,51$; s K-ABC $r=0,68$ ), ale podrobnější výsledky byly nejednoznačné. Další malá studie byla provedena na 12 dětech s hraničním intelektem a MR. I v této studii spolu CAS2 a WISC-III korelovaly $(r=0,62)$. Vzhledem k nízkému počtu probandů se ovšem dají tyto studie nazývat spíše pilotními, což uznávají i autoři české standardizace, kteří volají po dalším relevantním výzkumu. Hodnocení validity se tak (podobně jako u reliability) do velké míry opírá o výzkumy týkající se anglické verze testu.

\section{Normy}

Původní americké normy jsou zpracovány velice kvalitně. Při stratifikaci vzorku ( $N=1342)$ bylo zohledněno velké množství základních demografických charakteristik: Věk, pohlaví, oblast USA, etnikum, hispánský původ, konkrétní typ speciálních vzdělávacích potřeb, př́ijem rodiny a vzdělání rodičů. Obzvláště oceňuji snahu o poměrné zastoupení konkrétních typů speciálních vzdělávacích potřeb. Toto úsilí se autorům vyplatilo tím, že jim umožnilo získat podrobnější analýzou standardizačního vzorku další důkazy podporující validitu testu (viz výše).

V České republice byl proveden kvótní výběr vzorku $(N=896)$ podle věku, pohlaví, velikosti místa bydliště, vzdělání rodičů a speciálních vzdělávacích potřeb probandů. Bohužel na úrovni vzdělávacích potřeb zůstal na hrubém rozlišení výskyt/nevýskyt. Také se nepodařilo zcela uspokojivě zajistit adekvátní zastoupení probandů s rodiči se základním vzděláním (ve vzorku 3,9 \%, dle ČSÚ z 20148 \%) a výučním listem (ve vzorku 26,6 \%, dle ČSÚ z 201439 \%). To může vést k podhodnocování výsledků vyšetřených osob. České normy také postrádají jakékoli zohlednění minorit, přičemž autoři lokální verze argumentují homogenitou populace ČR. 


\section{Závěr}

V souladu se závěry zahraničních recenzentů (Acheson, 2017; Champ Morera, 2017; McGill, 2015) považujeme CAS2 za originální metodu, která je velice jednoduše administrovatelná a jež má kvalitně zpracované testové materiály. CAS2 oproti jiným dostupným testům kognitivních schopností nabízí ipsativní analýzu, tedy na statistice založenou identifikaci silných a slabých stránek probanda. Skóry testu mohou s určitou opatrností posloužit k identifikaci nadání či ověření hypotézy o mentální retardaci. Test neposkytuje zcela jasná vodítka pro diagnostiku všeho ostatního, co podle autorů diagnostikovat má (ADHD, poruchy učení, traumatické poranění mozku, vážné emoční poruchy). Analýzou jeho výsledků se může psycholog dobrat k zajímavým závěrům, které jeho diagnostické úvahy podstatně zpřesní. Jeho možné využití tedy spatřujeme jak v oblasti klinické, tak voblasti školsky poradenské. Dokonce můžeme na základě výzkumu (Naglieri et al., 2006) spekulovat o tom, že výsledky CAS2 lépe korelují $\mathrm{s}$ akademickým úspěchem než výsledky WISC-III.

Původní důkazy validity a reliability na amerických vzorcích jsou přes jisté výhrady dostatečně přesvědčivé. Bohužel obdobně silné důkazy na českých vzorcích v materiálech naší verze chybí. Můžeme se domnívat, že vzhledem $\mathrm{k}$ typu položek testu se toho překladem př́liš změnit na reliabilitě a validitě nemohlo, ovšem je to skutečně pouze domněnka, která si žádá další ověření. V USA vyšly rovněž materiály, které na základě výsledků CAS2 vytvárí plán intervencí. Ty bohužel v české lokalizaci nenajdeme. Autoři české verze testu jsou si však vědomí těchto nedostatků, nabádají k dalšímu výzkumu a spekulují nad překladem materiálů k intervencím.

Přes tyto nedostatky můžeme CAS2 doporučit s jistou opatrností k běžnému užívání, a to hlavně díky aktuálním českým normám vytvořeným na základě poměrně velkého standardizačního souboru. Je však nutné počítat $s$ tím, že normy jsou pravděpodobně o něco „tvrdší $v$ důsledku nižšího zastoupení rodičů respondentů s nižším vzděláním.

\section{Deklarace střetu zájmů}

Autor recenze se podílel na sběru standardizačních dat recenzovaného testu a byl za tuto činnost honorován distributorem testu. Autor prohlašuje, že tyto okolnosti neměly vliv na výsledné posouzení a vyznění této recenze.

Vznik recenze byl finančně podpořen Národním ústavem pro vzdělávání. 


\section{Zdroje}

Acheson, S. K. (2017). Test review of Cognitive Assessment System-Second Edition. In J. F. Carlson, K. F. Geisinger, \& J. L. Jonson (Eds.), The twentieth mental measurements yearbook. Dostupné z http://marketplace.unl.edu/buros/

Champ Morera, C. A. (2017). Test review of Cognitive Assessment System-Second Edition. In J. F. Carlson, K. F. Geisinger, \& J. L. Jonson (Eds.), The twentieth mental measurements yearbook. Dostupné z http://marketplace.unl.edu/buros/

Das, J. P., Kirby, J. R., \& Naglieri, J. A. (1994). Assessment of cognitive processes: the PASS theory of intelligence. Boston: Allyn and Bacon.

Hu, L., \& Bentler, P. M. (1999). Cutoff criteria for fit indexes in covariance structure analysis: Conventional criteria versus new alternatives. Structural Equation Modeling: A Multidisciplinary Journal,6(1), 1-55. doi: 10.1080/10705519909540118

Ježek, S. (2010). Standardy pro užívání psychologických testů - nastal čas pro českou normu? Testfórum, 1(1), 18-22. doi: 10.5817/TF2010-1-5

Kranzler, J. H., \& Keith, T. Z. (1999). Independent confirmatory factor analysis of the Cognitive Assessment System: What does the CAS measure? School Psychology Review, 28, 117-144.

Lurija, A. R. (1973). The working brain: an introduction to neuropsychology. New York, NY: Basic Books.

Mcgill, R. J. (2015). Test Review: Naglieri, J. A., Das, J. P., \& Goldstein, S. (2014). Cognitive Assessment System-Second Edition (2nd ed.). Austin, TX: Pro-Ed. Journal of Psychoeducational Assessment, 33(4), 375-380. doi: 10.1177/0734282914566123

Naglieri, J. A., Lauder, B. Y., Goldstein, S., \& Schwebech, A. (2006). WISC-III and CAS: Which Correlates Higher with Achievement for a Clinical Sample? School Psychology Quarterly,21(1), 62-76. doi: 10.1521/scpq.2006.21.1.62

Propsyco. (2017a). CAS2. Dostupné 26.12. 2017, z http://shop.propsyco.cz/product.php?id_product=27.

Propsyco. (2017b). Jak na to. Dostupné 26.12. 2017, z http://shop.propsyco.cz/cms.php?id_cms=7. 


\section{MODEL RECENZE PODLE EFPA PRO POPIS \\ A HODNOCENÍ PSYCHOLOGICKÝCH TESTŮ \\ FORMULÁŘ RECENZE TESTU A POZNÁMKY PRO \\ RECENZENTY ${ }^{1}$}

Toto je lokální úprava dokumentu pro účely publikace v časopise Testfórum.

Originální český překlad je k dispozici na stránkách EFPA

(www.efpa.eu/download/505cd9db4144ecb16174087909c9cd6d).

Původní verzi sestavil a uspořádal Dave Bartram

Doplnili a revidovali Patricia Lindley, Dave Bartram a Natalie Kennedy v dubnu $2004^{2}$

Současná verze 3.42: květen 2005

Český překlad: Tomáš Urbánek

Od uživatelů tohoto dokumentu a jeho obsahu žádá EFPA, aby uznali tento zdroj prostřednictvím následujícího textu:

"Kritéria pro recenzi testu podle EFPA do značné míry vychází z formy a obsahu kritérií pro recenze testů Britské psychologické společnosti (BPS) a kritérií vytvořených Komisí pro testové záležitosti (COTAN) Holandské asociace psychologů (NIP). Dave Bartram a Patricia Lindley původně vyvinuli kritéria BPS a recenzní procedury pro UK Employment Service a později rozšírili jejich používání pro celou BPS. Arne Evers připravil k vydání nizozemský system posuzování kvality testů.

EFPA je vděčná BPS a NIP za svolení použít jejich kritéria jako základ pro vytvoření evropského modelu. EFPA je také vděčná Davu Bartramovi, Arnu Eversovi a Patricii Lindley za jejich přispění $k$ vývoji tohoto modelu. Veškerá intelektuální vlastnická práva původních kritérií podle BPS a NIP jsou nadále uznávána a náleží těmto orgánům."

\footnotetext{
1 Tento dokument byl vytvořen z několika zdrojů, včetně Hodnotícího formuláře pro recenzi testu používaného v BPS (NPAL a Řídící komise pro testové standardy při BPS - Steering Committee on Test Standards), Španělského dotazníku pro hodnocení psychometrických testů (Španělská psychologická asociace) a Systému pro posuzování kvality testu (Komise pro testování Holandské asociace psychologů). Některé části byly adaptovány se svolením z dokumentu: BPS Books Reviews of Level B Assessment Instruments for use in Occupational Assessment, Notes for Reviewers: Version 3.1. December 1998: Copyright (C) NPAL, 1989, 1993, 1998.

${ }^{2}$ Současná verze je spojením dvou oddělených dokumentů (Formuláře recenze a Poznámek pro recenzenty). Obsah byl navíc uspořádán a doplněn na základě jeho používání recenzenty online testů v BPS.
} 


\section{Část 1:}

Popis nástroje: Obecné informace a klasifikace

\begin{tabular}{|c|c|c|}
\hline & Recenzent 1: & Mgr. Martin Pírko \\
\hline & Recenzent 2: & \\
\hline & Konzultující editor: & Mgr. Jaroslav Točík \\
\hline & Vedoucí editor: & Mgr. Hynek Cígler, Ph.D. \\
\hline & $\begin{array}{l}\text { Vedoucí editor aktualizace: } \\
\text { (pouze v př́ípadě aktualizací) }\end{array}$ & \\
\hline & $\begin{array}{l}\text { Editor aktualizace: } \\
\text { (pouze v př́padě aktualizací) }\end{array}$ & \\
\hline & Datum vzniku této recenze: & 24. 12.2017 \\
\hline 1.1 & Název nástroje (lokální verze): & $\begin{array}{l}\text { Diagnostická baterie kognitivních procesů } \\
\text { (Cognitive Assessment System), druhé } \\
\text { vydání }\end{array}$ \\
\hline & Zkrácená verze názvu testu: & CAS2 \\
\hline 1.2 & $\begin{array}{l}\text { Původní název testu (pokud je lokální } \\
\text { verze adaptací): }\end{array}$ & $\begin{array}{l}\text { Cognitive Assessment System - Second } \\
\text { Edition }\end{array}$ \\
\hline 1.4 & Autoři původního testu: & $\begin{array}{l}\text { Jack A. Naglieri, Jagannath P. Das, Sam } \\
\text { Goldstein }\end{array}$ \\
\hline $\begin{array}{l}1.3 \\
\end{array}$ & Autoři lokální adaptace: & Lenka Krejčová \\
\hline 1.7 & Lokální distributor/vydavatel testu: & Propsyco, s. r. o. \\
\hline 1.8 & $\begin{array}{l}\text { Vydavatel původní verze testu (pokud je } \\
\text { jiný než současný distributor/vydavatel): }\end{array}$ & PRO-ED, Inc. \\
\hline 1.9 .1 & Datum vydání současné revize/vydání: & 2014 \\
\hline 1.9 .2 & $\begin{array}{l}\text { Datum vydání adaptace pro lokální } \\
\text { užívání: }\end{array}$ & 2017 \\
\hline 1.9 .3 & Datum vydání původního testu: & 1997 \\
\hline
\end{tabular}




\section{Obecný popis nástroje}

Diagnostická baterie kognitivních procesů (Cognitive Assessment Systém), druhé vydání (dále ve zkratce CAS2) představuje soubor individuálně administrovaných psychodiagnostických metod, který má za úkol zjistit úroveň neurokognitivních procesů (Plánování, Pozornost, Následné a Simultánní procesy) dětí, dospívajích a mladých dospělých od 5 do 18 let včetně.

CAS2 navazuje na inteligenční teorii kognitivního zpracování PASS, kterou vytvořila trojice amerických autorů Das, Naglieri a Kirby (1994) a která vychází z poznatků ruského neuropsychologa Alexandra Luriji (1973) o modularitě a vzájemné propojenosti mozku a o třech základních funkčních jednotkách kognitivních procesů. Das, Naglieri a Kirby tento základ postupně přetvořili v model čtyř základních procesů práce $\mathrm{s}$ informacemi a řešení problémů PASS: $\mathrm{P}$ (planning) = plánování, $\mathrm{A}$ (attention) $=$ pozornost, $\mathrm{S}$ (simultaneous) $=$ simultánní zpracování, S (successive) = následné zpracování. Tento model slouží dle autorů $\mathrm{k}$ tomu, aby nám pomohl porozumět povaze individuálních rozdílů, aby nám poskytl rámec pro vyšetření a aby nás vedl př́mo k podpoře založené na teorii.

Čtyři základní procesy jsou v rámci teorie popsány následovně. Plánování se používá k rozhodování, sebepozorování, autokorekci, k řízení myšlenek a činností. Pozornost je využívána pro selektivní soustředění na určitý podnět a zároveň k potlačování reakcí na podněty jiné. Simultánní zpracování spojuje oddělené podněty do jednoho celku, a to jak neverbálně-prostorové, tak verbálně-gramatické. Následné zpracování integruje informace do určitého lineárního sledu a umožňuje například porozumět významu vyprávění.

Test CAS2 se skládá celkem ze 13 subtestů, které mohou složit bud' základní ( 8 subtestů) nebo rozšířenou (12 subtestů) baterii. Administrace trvá přibližně 60 minut (základní) nebo 90 minut (rozšířená baterie). Testování probíhá formou tužka-papír, případně rozhovorem. Výsledkem metody je soubor vážených skóru jednotlivých subtestů, které skládají čtyři škálové skóry základních procesů dle teorie PASS. K dispozici je i celková škála kognitivních procesů, ale kromě ní i odvozené skóry exekutivních funkcí a pracovní paměti.

Autoři původní verze metody uvádí v technickém a interpretačním manuálu metody, že prezentovaný test nabízí multidimenzionální úplné hodnocení základních neurokognitivních schopností přesahujících obecnou inteligenci. Dále tvrdí, že test odhaluje specifické kognitivní problémy související s konkrétními studijními neúspěchy, je relevantní pro intervenci, správně diagnostikuje jednotlivce ze znevýhodněných skupin a funguje napříc kulturami a zvyky. Autoři nabízí v návaznosti na vyšetření CAS2 v USA komerční intervenční programy zaměřené na kognitivní obohacení COGENT a PREP.

Česká standardizace proběhla na 896 probandech, přičemž při výběru zohlednila věk, pohlaví, velikost sídla, speciální vzdělávací potřeby a vzdělání rodičů. Důkazy o validitě a reliabilitě metody však vychází povětšinou ze studií autorů původní americké verze, primárně z původní standardizační studie $(N=1342)$. 


\section{Část 2:}

\section{Klasifikace}

\begin{tabular}{|c|c|c|}
\hline 1.10 .1 & Obsahová doména & 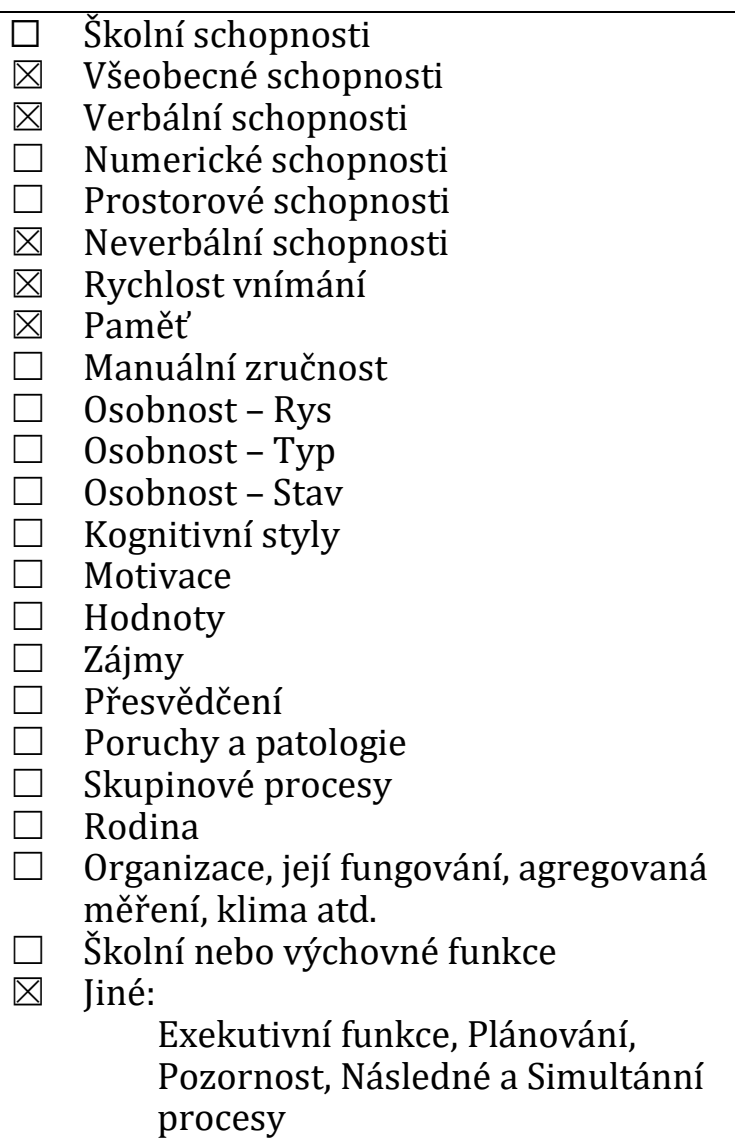 \\
\hline 1.10 .2 & $\begin{array}{l}\text { Zamýšlená(é) nebo hlavní oblast(i) } \\
\text { použití. }\end{array}$ & $\begin{array}{ll} & \text { Klinická psychologie } \\
\bigotimes & \text { Neuropsychologie } \\
\square & \text { Forenzní psychologie } \\
\bigotimes & \text { Psychologie výchovy a vzdělávání } \\
\square & \text { Psychologie práce a personalistika } \\
\square & \text { Poradenství, doporučení, vedení a volba } \\
& \text { povolání } \\
\square & \text { Psychologie zdraví, životní styl a životní } \\
& \text { spokojenost } \\
\square & \text { Sporty a volný čas } \\
\square & \text { Jiné: }\end{array}$ \\
\hline
\end{tabular}




\begin{tabular}{|c|c|c|}
\hline 1.10 .3 & $\begin{array}{l}\text { Zamýšlený způsob použití } \\
\text { (podmínky, za jakých byl nástroj } \\
\text { standardizován a validizován) }\end{array}$ & $\begin{array}{l}\square \text { Nesupervidovaná administrace bez } \\
\text { kontroly nad identitou respondenta a bez } \\
\text { úplné kontroly nad podmínkami } \\
\text { administrace (např. volně přístupný test } \\
\text { na internetu, test dostupný ke koupi v } \\
\text { knihkupectví). } \\
\square \text { Kontrolovaný nesupervidovanou } \\
\text { administrcí. Kontrola nad podmínkami } \\
\text { (čas atd.) a určitá kontrola nad identitou } \\
\text { uživatele testu (např. testy } \\
\text { administrované přes internet, ale pouze } \\
\text { známým osobám - př́ístup omezený } \\
\text { heslem). } \\
\text { Supervidovaná a kontrolovaná } \\
\text { administrace. Administrace testu pod } \\
\text { kontrolou kvalifikovaného adminitrátora } \\
\text { nebo dohlížitele. } \\
\text { Řízená administrace. Administrace testu } \\
\text { prováděná pouze přes určená testovací } \\
\text { centra (např. programy hodnocení licencí } \\
\text { a certifikace). }\end{array}$ \\
\hline $\begin{array}{l}1.10 .4 \\
\end{array}$ & $\begin{array}{l}\text { Popis populací, pro které je test } \\
\text { určen: }\end{array}$ & $\begin{array}{l}\text { Děti, dospívající a mladí dospělí ve věku 5-18 } \\
\text { let. }\end{array}$ \\
\hline 1.10 .5 & $\begin{array}{l}\text { Počet škál a krátký popis } \\
\text { proměnné nebo proměnných } \\
\text { měřených nástrojem }\end{array}$ & $\begin{array}{l}\text { Test má dvě formy, základní a rozšířenou } \\
\text { baterii (údaje k ní v závorkách), každá z nich } \\
\text { je složena ze } 4 \text { škál PASS - Plánování, } \\
\text { Pozornosti, Simultánních a Následných } \\
\text { procesủ. Každá ze } 4 \text { škál PASS se dále sestává } \\
\text { ze } 2 \text { (3) subtestů: } \\
\text { Plánování - Plánované kódování, Plánované } \\
\text { spojení (a Plánované párování čísel); } \\
\text { Plánování se používá k rozhodování, } \\
\text { sebepozorování, autokorekci, k řízení } \\
\text { myšlenek a činností. } \\
\text { Pozornost - Expresivní pozornost, Hledání } \\
\text { čísel (a Receptivní pozornost); Pozornost je } \\
\text { využívána pro selektivní soustředění na } \\
\text { určitý podnět a zároveň k potlačování reakcí } \\
\text { na podněty jiné. } \\
\text { Simultánní procesy - Matrice, Verbálně- } \\
\text { prostorové vztahy (a Figurální pamét'); } \\
\text { Simultánní procesy spojují oddělené podněty } \\
\text { do jednoho celku, a to jak neverbálně- } \\
\text { prostorové, tak verbálně-gramatické. } \\
\text { Následné procesy - Slovní řady, Opakování } \\
\text { vět pro osoby ve věku 5-7 let nebo Otázky pro } \\
\text { osoby ve věku 8-18 let (a Opakování viděných } \\
\text { čísel); Následné procesy integrují informace } \\
\text { do určitého lineárního sledu a umožňují } \\
\text { například porozumět významu vyprávění. }\end{array}$ \\
\hline
\end{tabular}




\begin{tabular}{|c|c|c|}
\hline & & $\begin{array}{l}\text { Součtem všech } 4 \text { škál získáme Celkovou škálu } \\
\text { (u základní i rozšířené verze). } \\
\text { Test dále nabízí } 5 \text { odvozených škál tvořených } \\
\text { konkrétními subtesty: } \\
\text { Exekutivní funkce bez pracovní paměti - } \\
\text { Plánované spojení, Expresivní pozornost } \\
\text { Exekutivní funkce s pracovní pamétí - } \\
\text { Plánované spojení, Expresivní pozornost, } \\
\text { Verbálně-prostorové vztahy, Opakování } \\
\text { vět/Otázky } \\
\text { Pracovní pamět' - Verbálně-prostorové } \\
\text { vztahy, Opakování vět/Otázky } \\
\text { Verbální obsah - Verbálně-prostorové vztahy, } \\
\text { Opakování vět/Otázky, Receptivní pozornost } \\
\text { Neverbální obsah - Plánované kódování, } \\
\text { Matrice, Figurální pamět' }\end{array}$ \\
\hline 1.11 & Formát položek & $\begin{array}{ll} & \text { Otevřený } \\
\square & \text { Mnohonásobná volba, alternativy na } \\
& \text { stejné škále } \\
\square & \text { Bipolární adjektiva } \\
\square & \text { Likertovy ratingy (škály) } \\
\square & \text { Nucená volba, alternativy na smíšených } \\
\text { škálách (ipsativní) - vysvětlení viz } \\
\text { Poznámky } \\
\square \text { Mnohonásobná volba, alternativy na } \\
\text { smíšených škálách (ipsativní) - } \\
\text { vysvětlení viz Poznámky } \\
\square \quad \text { Sady párů adjektiv (sémantický } \\
\text { diferenciál), smíšené škály (ipsativní) } \\
\square \quad \text { Jiné: }\end{array}$ \\
\hline
\end{tabular}




\begin{tabular}{|c|c|c|}
\hline 1.12 & Počet položek testu: & $\begin{array}{l}\text { Dle subtestů: } \\
\text { Plánované kódování - } 128 \text { (ve } 4 \text { souborech) } \\
\text { Plánované spojení - } 7 \\
\text { Plánované párování čísel - } 16 \text { (ve } 2 \text { souborech, } \\
5-7 \text { let), } 24 \text { (ve } 3 \text { souborech, } 8-18 \text { let) } \\
\text { Matrice - } 44 \text { (od } 12 \text { let začínají na } 12 \text {. položce) } \\
\text { Verbálně prostorové vztahy - } 40 \text { (od } 8 \text { let } \\
\text { začínají na } 7 \text {. položce) } \\
\text { Figurální pamět' - } 37 \text { (od } 8 \text { let začínají na } 10 . \\
\text { položce) } \\
\text { Expresivní pozornost - } 126 \text { (5-7 let), } 120 \text { (8- } \\
18 \text { let; pro obě věkové skupiny } 3 \text { soubory) } \\
\text { Hledání čísel - } 864 \text { (ve } 4 \text { souborech) } \\
\text { Receptivní pozornost - } 240 \text { (5-7 let), } 720 \text { (8- } \\
18 \text { let; pro obě věkové skupiny ve } \\
\text { souborech) } \\
\text { Slovní řady - } 32 \text { (od } 8 \text { let začínají na } 5 \text {. položce) } \\
\text { Opakování vět (5-7 let) - } 27 \\
\text { Otázky (8-18 let) - } 25 \\
\text { Opakování viděných čísel - } 30 \text { (od } 8 \text { let začínají } \\
\text { na } 5 \text {. položce) } \\
\text { Např. základní baterie pro osoby staré } 5-7 \text { let } \\
\text { má tedy celkem } 1268 \text { položek (z toho } 1118 \\
\text { sestavených v } 15 \text { souborech položek). }\end{array}$ \\
\hline 1.13 & Způsob(y) administrace: & $\begin{array}{ll}\bigotimes & \text { Interaktivní individuální administrace } \\
\square & \text { Supervidovaná skupinová administrace } \\
\square & \text { Počítačová lokálně nainstalovaná } \\
\text { aplikace - pod supervizí/dohledem } \\
\square \\
\text { Počítačová aplikace na webu - pod } \\
\text { supervizí/dohledem } \\
\square \quad \text { Počítačová lokálně nainstalovaná } \\
\text { aplikace - bez supervise/testování sebe } \\
\square \quad \text { Počítačová aplikace na webu - bez } \\
\text { supervize/testování sebe } \\
\square \text { Jiné: }\end{array}$ \\
\hline 1.14 & Způsob odpovídání: & $\begin{array}{ll}\bigotimes & \text { Ústní rozhovor } \\
\bigotimes & \text { Papír a tužka } \\
\square & \text { Manuální operace } \\
\square & \text { Na počítači } \\
\square & \text { Jiné: }\end{array}$ \\
\hline
\end{tabular}




\begin{tabular}{|c|c|c|c|}
\hline 1.15 & 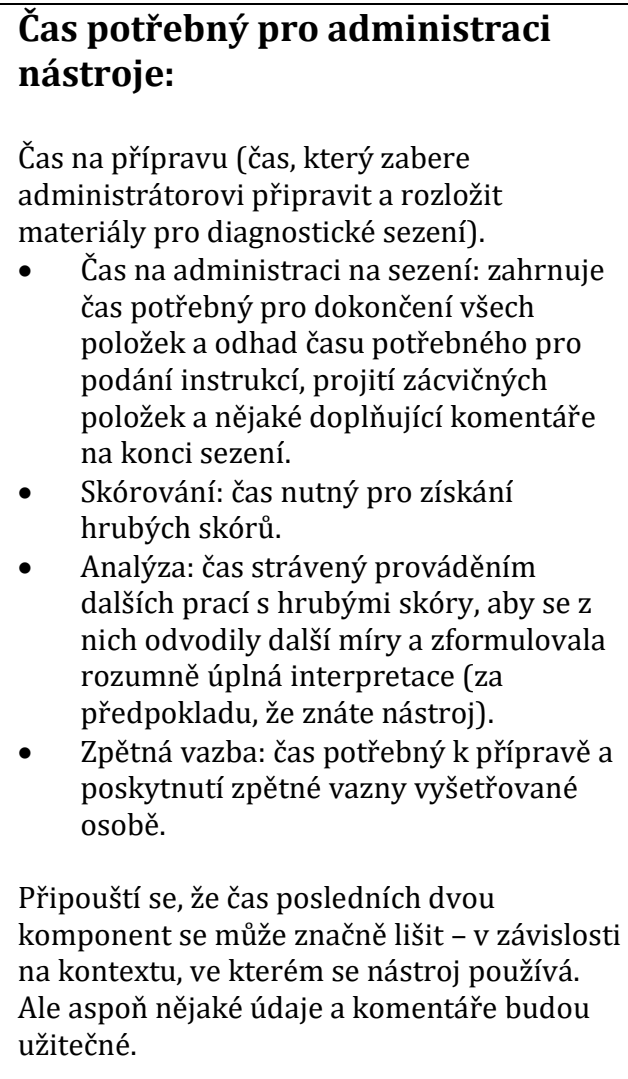 & $\begin{array}{l}\text { Skórování: } \\
\text { Analýza: } \\
\text { Zpětná vazba: } \\
\text { - * odhad ze zku } \\
\text { - ** údaj z webov } \\
\text { (Propsyco, 201 } \\
\text { - ** test umožňu } \\
\text { množství skóru } \\
\text { srovnávat a hle } \\
\text { stránky proban } \\
\text { významně prod }\end{array}$ & $\begin{array}{l}5 \text { min* } \\
60 \text { min u základní a } 90 \\
\text { min u rozšířené } \\
\text { baterie** } \\
20 \text { min* } \\
45 \text { min*** } \\
45 \text { min * } \\
\text { šenosti recenzenta } \\
\text { ych stránek vydavatele } \\
\text { b) } \\
\text { je dopočítat velké } \\
\text { dovoluje skóry účelně } \\
\text { lat tak silné a slabé } \\
\text { la, což celou analýzu } \\
\text { užuje }\end{array}$ \\
\hline 1.16 & $\begin{array}{l}\text { Jsou k dispozici různé formy } \\
\text { nástroje? }\end{array}$ & \multicolumn{2}{|c|}{$\begin{array}{l}\text { U nás v ČR je zatím lokalizovaná pouze } \\
\text { recenzovaná verze metody obsahující } \\
\text { základní a rozšírenou baterii. V anglicky } \\
\text { mluvících zemích je ještě k dispozici } \\
\text { zkrácená verze CAS2: Brief a verze } \\
\text { pracující s posuzovacími šklálami pro } \\
\text { učitele CAS2: Rating Scale. }\end{array}$} \\
\hline
\end{tabular}

\begin{tabular}{|c|c|c|c|}
\hline 1.17 & Procedura skórování testu: & & $\begin{array}{l}\text { Počítačové skórování s přímým vstupem } \\
\text { odpovědí testovanou osobou } \\
\text { Počítačové skórování s ručním vstupem } \\
\text { odpovědí z papírového záznamového archu } \\
\text { Počítačové skórování odpovědí z papírového } \\
\text { záznamového archu pomocí pomocí jejich } \\
\text { načtení pomocí skeneru } \\
\text { Jednoduchý ruční skórovací klíč - nutné } \\
\text { pouze kancelářské dovednosti } \\
\text { Komplexní ruční skórování - vyžadující } \\
\text { trénink ve skórování nástroje } \\
\text { Služby zpracovnání dat - např. skórování } \\
\text { společností prodávající nástroj } \\
\text { Jiné: }\end{array}$ \\
\hline
\end{tabular}




\begin{tabular}{|c|c|c|}
\hline 1.18 & Skóry: & $\begin{array}{l}\text { U subtestů s jednoznačnou možností odpovědí } \\
\text { (Matice, Verbálně-prostorové vztahy, Figurální } \\
\text { pamět', Slovní řady, Opakování vět/Otázky, } \\
\text { Opakování viděných čísel) je stanoveno } \\
\text { hodnocení } 1 \text { nebo } 0 \text { bodů. Hrubě skóry těchto } \\
\text { subtestů jsou dány součtem správných odpovědí. } \\
\text { U subtestů Plánované kódování, plánované } \\
\text { párování čísel a Expresivní pozornost je třeba } \\
\text { zaznamenat počet správných odpovědí a } \\
\text { výsledný čas řešení úkolù probandem. Poté se } \\
\text { použije převodní tabulka poměrových skórů. } \\
\text { U subtestů Hledání čísel a Receptivní pozornost } \\
\text { se postupuje obdobně, jen se od správných } \\
\text { odpovědí odečítá počet chyb. } \\
\text { U subtestu Plánované spojení je hrubý skór } \\
\text { prostým součtem všech zaznamenaných časů } \\
\text { potřebných k vyřešení úloh. } \\
\text { Hrubé skóry jsou následně převedeny na vážené } \\
\text { skóry, ty jsou sečteny do škálových skórů a } \\
\text { celkového skóru. Tyto se následně převedou na } \\
\text { standardní skóry (průměr 100, sd = 15), } \\
\text { př́ípadně na percentily. Následně se srovnají } \\
\text { jednotlivé hodnoty s prưměrně dosaženými } \\
\text { skóry a určí se silné a slabé stránky probanda (na } \\
\text { úrovni škálových skórů i jednotlivých jejich } \\
\text { subtestů). Je možné dále spočítat i doplňkové } \\
\text { kombinované skóry. }\end{array}$ \\
\hline 1.19 & $\begin{array}{l}\text { Transformace skóru na standardní } \\
\text { skóry: }\end{array}$ & $\begin{array}{ll}\otimes & \text { Normalizovaná - skóry se získají použitím } \\
\text { normalizační tabulky } \\
\square \\
\text { Nenormalizovaná - skóry se získají lineární } \\
\text { transformací }\end{array}$ \\
\hline 1.20 & Použité škály & 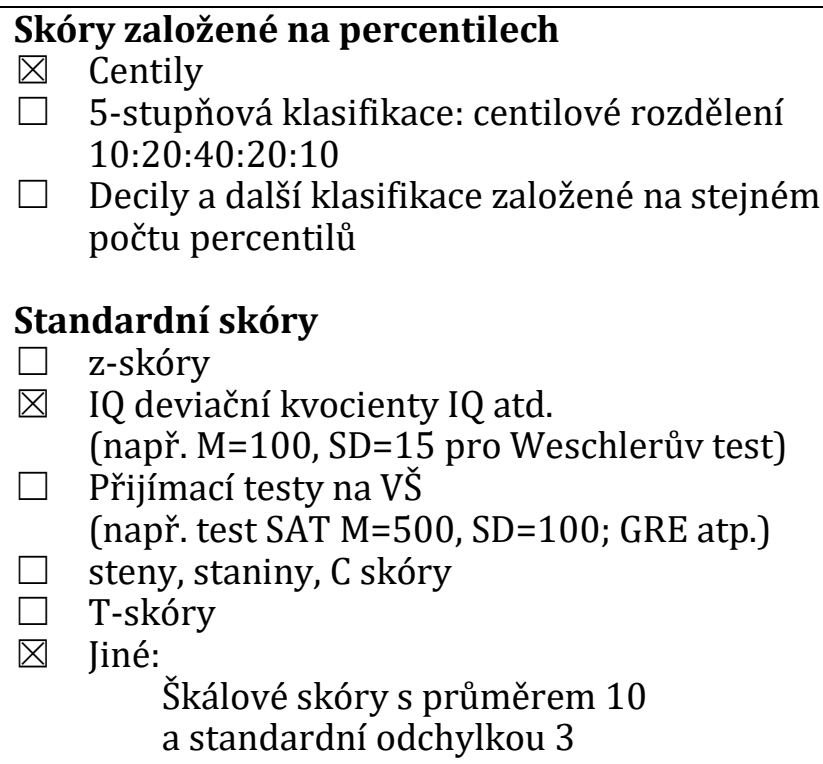 \\
\hline
\end{tabular}




\section{Část 4:}

\section{Počítačově generované zprávy}

Toto je čistě popisné. Hodnocení zpráv bude součástí části recenze nazvané Hodnocení.

\begin{tabular}{|l|l|ll|}
\hline 1.21 & $\begin{array}{l}\text { Jsou počítačově generované zprávy } \mathbf{k} \\
\text { dispozici s nástrojem? }\end{array}$ & $\square$ Ano \\
& $\bigotimes \quad \mathrm{Ne}$ \\
\hline
\end{tabular}

\section{Část 5:}

\section{Nabídka, podmínky a náklady}

Tato část definuje, co vydavatel poskytne, komu, za jakých podmínek a za jaké ceny. Definuje podmínky kladené dodavatelem a týkající se toho, kdo smí a kdo nesmí získat materiál nástroje. Pokud jedna z možností neodpovídá podmínkám nabídky, doplňte popis relevantních podmínek.

\begin{tabular}{|c|c|c|}
\hline 1.23 & $\begin{array}{l}\text { Dokumentace poskytovaná } \\
\text { distributorem jako součást } \\
\text { testového balíku }\end{array}$ & $\begin{array}{ll}\otimes & \text { Uživatelský manuál } \\
\bigotimes & \text { Technický (psychometrický) manuál } \\
\bigotimes & \text { Doplňkové technické informace a aktualizace } \\
\text { (např. lokální normy, lokální validizační studie } \\
\text { atd.) } \\
\square \\
\begin{array}{l}\text { Rozšiřující informace v podobě knih a článků k } \\
\text { tématu }\end{array} \\
\square & \text { Kombinace výše uvedených (uved'te) }\end{array}$ \\
\hline 1.24 & Metody publikace & $\begin{array}{ll}\otimes & \text { Papír } \\
\square & \text { PC - Diskety } \\
\square & \text { PC - CD/ROM } \\
\square & \text { Download z internetu } \\
\square & \text { Živý internet (nástroj pracuje v internetovém } \\
& \text { prohlížeči) } \\
\square & \text { Jiné: }\end{array}$ \\
\hline 1.25 .1 & $\begin{array}{l}\text { Počáteční náklady. } \\
\text { Cena kompletní sady materiálů (všechny manuály a } \\
\text { další material nutný k aspoň jedné zkušební } \\
\text { administraci). Kolik uchazečú lze vyšetřovat pomocí } \\
\text { materiálu získaných za počáteční náklady, kde tyto } \\
\text { náklady zahrnují materially pro opakované vyšetř̌ení. }\end{array}$ & $\begin{array}{l}\text { Kompletní sada CAS2 obsahuje Administrativní a } \\
\text { skórovací manuál; Interpretační a technický } \\
\text { manuál; Podnětový sešit, část I: Matice, Verbálně- } \\
\text { prostorové vztahy; Podnětový sešit, část 2: Figurální } \\
\text { pamět', Expresivní pozornost; Podnětový sešit část } \\
\text { 3: Opakování viděných čísel; Skórovací šablony; } 25 \\
\text { záznamových sešitů; } 10 \text { Pracovních sešitů pro věk 5- } \\
7 \text { let; } 15 \text { Pracovních sešitů pro věk 8-18 let; a } 25 \\
\text { Pracovních sešitů pro Figurální pamět' pro věk 5-18 } \\
\text { let. Vše v plátěné tašce s ramenním popruhem. Cena } \\
\text { této sady je aktuálně } 21315 \text { Kč. } \\
\text { Vydavatel metody dále doporučuje } \\
\text { administrátorům zúčastnit se školení pořádaného } \\
\text { DYS-centrum } \circledast \text { Praha z.ú. (aktuální cena } 1300 \text { Kč). }\end{array}$ \\
\hline
\end{tabular}




\begin{tabular}{|c|c|c|}
\hline 1.25 .2 & Opakující se náklady: & $\begin{array}{l}\text { V případě administrace nad rámec } 10 \text { osob ve věku } \\
\text { 5-7 let nebo } 15 \text { osob ve věku } 8-18 \text { let je třeba } \\
\text { dokoupit příslušné pracovní sešity: } \\
\text { CAS2 - Pracovní sešit } 5-7 \text { let }(10 \mathrm{ks})-450 \text { Kč } \\
\text { CAS2 - Pracovní sešit } 8-18 \text { let (15 ks) - } 450 \text { Kč } \\
\text { CAS2 - Pracovní sešit- figurální pamět' ( } 25 \mathrm{ks})-500 \\
\text { Kč }\end{array}$ \\
\hline 1.26 .1 & $\begin{array}{l}\text { Ceny za zprávy generované } \\
\text { softwarem nainstalovaným } \\
\text { uživatelem: }\end{array}$ & \\
\hline 1.26 .2 & $\begin{array}{l}\text { Ceny za vyhotovení zprávy zaslené } \\
\text { prostřednictvím pošty/faxu: }\end{array}$ & \\
\hline 1.26 .3 & $\begin{array}{l}\text { Ceny za vyhotovení zprávy zaslené } \\
\text { prostřednictvím internetové služby: }\end{array}$ & \\
\hline 1.27 & $\begin{array}{l}\text { Ceny za další služby a zpracování } \\
\text { dat: opravy nebo vývoj } \\
\text { automatických zpráv: }\end{array}$ & \\
\hline 1.28 & 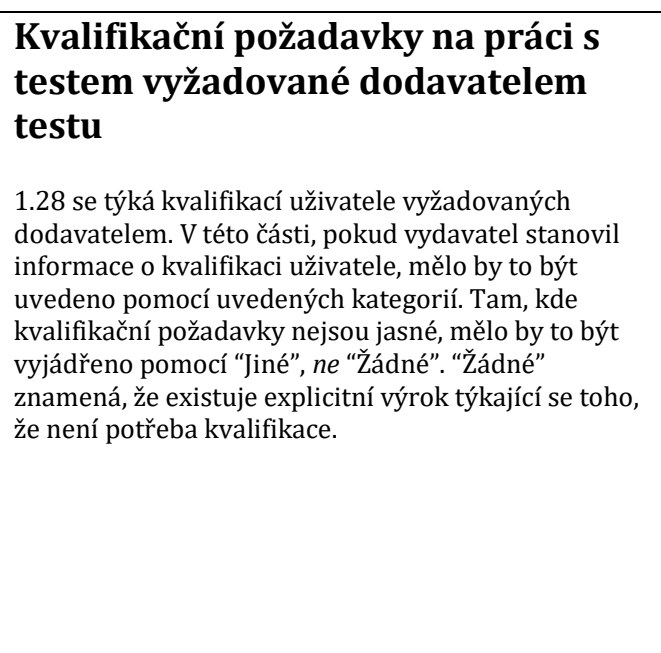 & 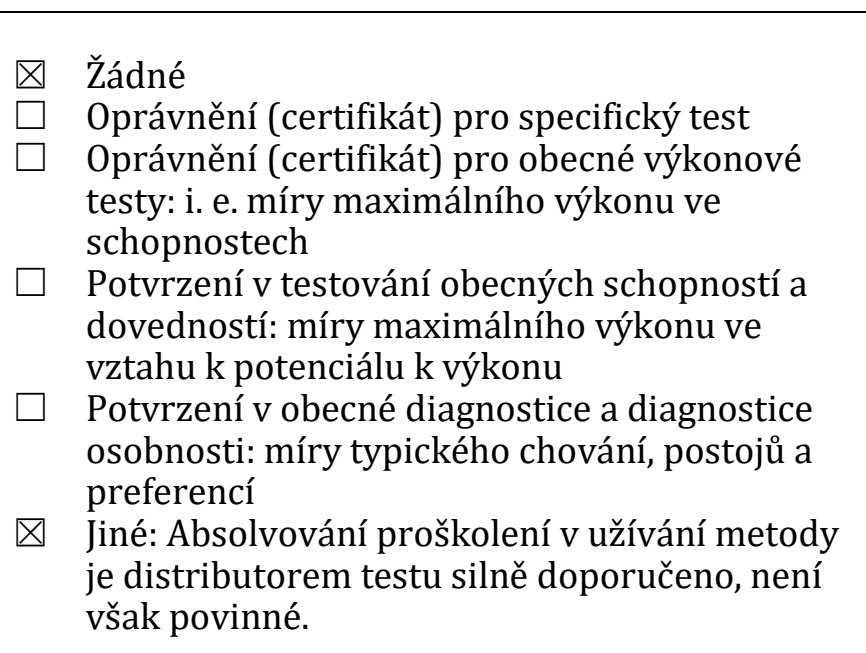 \\
\hline 1.29 & 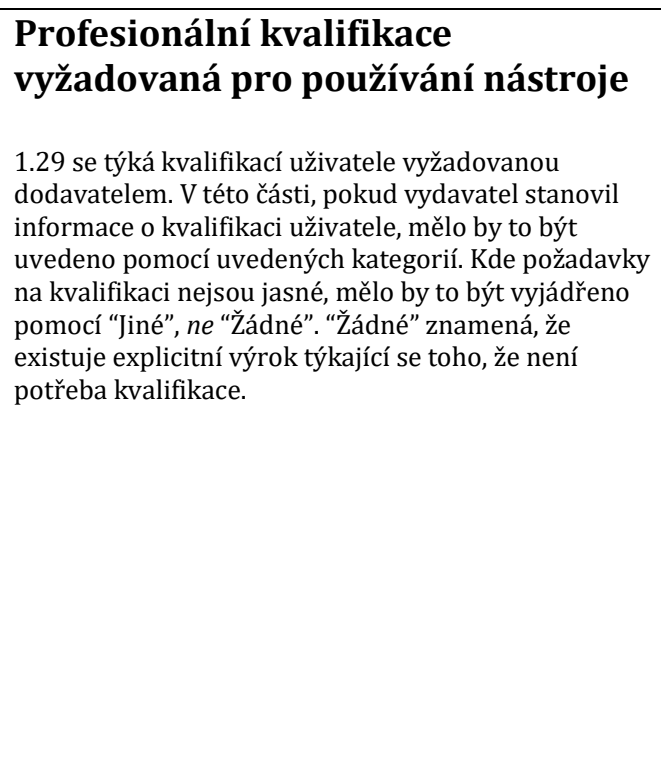 & $\begin{array}{ll}\square & \text { Žádné } \\
\square & \text { Praktický psycholog s kvalifikací v relevantní } \\
& \text { aplikační oblasti } \\
\square & \text { Praktický psycholog } \\
\square & \text { Výzkumný psycholog } \\
\square & \text { Nepsychologický akademický výzkumník } \\
\square & \text { Praktik v relevantních příbuzných profesích } \\
\text { (terapie, medicína, poradenství, vzdělání, } \\
\text { lidské zdroje atd.) } \\
\square \quad \text { Držitel Certifikátu způsobilosti pro testování } \\
\text { v psychologii práce A BPS } \\
\square \quad \text { Držitel Certifikátu způsobilosti pro testování } \\
\text { v oblastni vzdělávacím A BPS } \\
\square \quad \text { Držitel Certifikátu způsobilosti pro testování } \\
\text { v psychologii práce B BPS } \\
\square \quad \text { Jiné: } \\
\quad \text { Absolvent magisterského studia } \\
\text { psychologie }\end{array}$ \\
\hline
\end{tabular}



Č́st 6:

Hodnocení testových materiálů

\section{Vysvětlení hodnocení}

V následujících částech jsou celková posouzení adekvátnosti informací týkajících se validity, reliability a norem zobrazeny automaticky tučně.

Jakýkoli nástroj $s$ jedním nebo více posouzeními 0 nebo 2 týkajícími se atributů považovaných za kritické pro bezpečné používání nástroje, by neměl být považován za nástroj, který splňuje minimální standardy.

\begin{tabular}{|c|c|c|c|}
\hline $\begin{array}{l}\text { Vstup na posuzovacím } \\
\text { formuláři }\end{array}$ & $\begin{array}{l}\text { Posouzení podle } \\
\text { standardů EFPA }\end{array}$ & $\begin{array}{c}\text { Reprezentace recenze } v \\
\mathrm{UK}\end{array}$ & Vysvětlení \\
\hline [n/a] & [n/a ] & {$[\mathrm{n} / \mathrm{a}]$} & $\begin{array}{l}\text { Tento atribut není u tohoto } \\
\text { nástroje použitelný }\end{array}$ \\
\hline $\mathbf{0}$ & {$[-]$} & [None ] & $\begin{array}{c}\text { Není možné posoudit jako } \\
\text { ne nebo nedostatek } \\
\text { poskytnutých informací }\end{array}$ \\
\hline 1 & {$[-1]$} & {$\left[\begin{array}{ll}* & ]\end{array}\right.$} & Neadekvátní \\
\hline 2 & & {$\left[\begin{array}{ll}* * & ]\end{array}\right.$} & NYNÍ NEPOUŽÍVÁNO \\
\hline 3 & {$\left[\begin{array}{ll}0 & ]\end{array}\right.$} & {$\left[\begin{array}{ll}* * * & ]\end{array}\right.$} & Adekvátní nebo přiměřený \\
\hline 4 & {$\left[\begin{array}{ll}1 & 1\end{array}\right.$} & {$[* * * *]$} & Dobrý \\
\hline \multirow[t]{2}{*}{5} & [ 2 ] & {$[* * * * *]$} & Vynikající \\
\hline & & $\begin{array}{c}\text { [N.r.i.o.r] }{ }^{*} \text { (pouze pro } \\
\text { aktualizace) }\end{array}$ & $\begin{array}{l}\text { Položka nebyla v původní } \\
\text { recenzi posuzována }\end{array}$ \\
\hline
\end{tabular}

V této části má být provedeno více hodnocení různých aspektů nebo atributů dokumentace dodávané s nástrojem (nebo balíkem). Termín „dokumentace“ byl vybrán, aby pokrýval všechny ty materiály dodávané s nástrojem nebo snadno dostupné kvalifikovanému uživateli: např. manual administrátora; technické př́ručky; brožury s normami; dodatky k manuálu; aktualizace od vydavatelů/dodavatelů atd.

Položky mají být posuzovány n/a nebo 0 až 5 (poloviční rating je přijatelný)

Rating

\begin{tabular}{|c|c|c|}
\hline \multicolumn{2}{|r|}{$\begin{array}{l}\text { Kvalita vysvětlení principů, prezentace a kvalita poskytnuté informace: } \\
\text { (Tento celkový rating se získá použitím posouzení založeného na ratinzích daných pro položky } 2.1-2.8 \text { ) }\end{array}$} & 5 \\
\hline 2.1 & $\begin{array}{l}\text { Celkový rating kvality vysvětlení principů: (Tento celkový rating se získá použitím } \\
\text { posouzení založeného na hodnotách ratingů daných pro položky } 2.1 .1-2.1 .5)\end{array}$ & 5 \\
\hline 2.1 .1 & i) Teoretické základy konstruktů: & 5 \\
\hline 2.1 .2 & ii) Procedura vývoje testu: & 1 \\
\hline 2.1 .3 & iii) Důkladnost analýz položek a model analýzy položek: & 0 \\
\hline 2.1 .4 & iv) Vysvětlení obsahové validity: & 5 \\
\hline 2.1 .5 & v) Souhrn relevantního výzkumu: & 3 \\
\hline 2.2 & 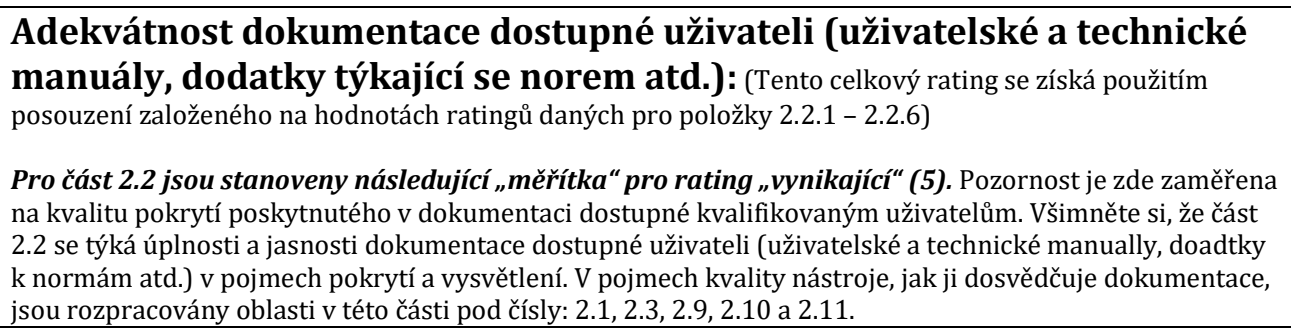 & 5 \\
\hline
\end{tabular}




\begin{tabular}{|c|c|c|}
\hline 2.2 .1 & $\begin{array}{l}\text { Principy: [viz 2.1] } \\
\text { Dobře argumentovaný a jasně prezentovaný popis toho, co má podle návrhu měřit a proč byl zkonstruován } \\
\text { tak, jak je. }\end{array}$ & 5 \\
\hline 2.2 .2 & $\begin{array}{l}\text { Vývoj: } \\
\text { Úplné detaily týkající se zdrojů položek, pilotáže, analýz položek, srovnávacích studií a změn prováděných v } \\
\text { prủběhu vývojových pokusŭ. }\end{array}$ & 1 \\
\hline 2.2 .3 & $\begin{array}{l}\text { Standardizace: } \\
\text { Jasné a detailní informace poskytnuté o velikostech a zdrojích standardizačního souboru a standardizační } \\
\text { proceduře. }\end{array}$ & 5 \\
\hline 2.2 .4 & $\begin{array}{l}\text { Normy: } \\
\text { Jasné a detailní informace poskytnuté o velikostech a zdrojích normalizačních skupin, podmínkách vyšetření } \\
\text { atd. }\end{array}$ & 5 \\
\hline 2.2 .5 & $\begin{array}{l}\text { Reliabilita: } \\
\text { Dobré vysvětlení reliability a široký rozsah měr vnitřní konsistence a retestu spolu s vysvětlením jejich } \\
\text { relevance a zobecnitelnosti nástroje vyšetření. }\end{array}$ & 5 \\
\hline 2.2 .6 & $\begin{array}{l}\text { Validita: } \\
\text { Dobré vysvětlení validity spolu s širokou škálou studií jasně a poctivě popsaných. }\end{array}$ & 5 \\
\hline 2.3 & $\begin{array}{l}\text { Kvalita procedurálních instrukcí poskytnutých uživateli: (Tento celkový rating se } \\
\text { získá s použitím posouzení na základě hodnot ratingů daných pro položky } 2.3 .1-2.3 .7)\end{array}$ & 4 \\
\hline 2.3 .1 & $\begin{array}{l}\text { Pro administraci testu: } \\
\text { Poskytnutá jasná a detailní vysvětlení a procedurální průvodce krok za krokem spolu s dobrými radami } \\
\text { týkajícícmi se otázek uchazeču a problémových situací. }\end{array}$ & 5 \\
\hline 2.3 .2 & $\begin{array}{l}\text { Pro skórování testu, normy atd.: } \\
\text { Poskytnuté jasné a detailní informace spolu s popsanými kontrolami pro vyhnutí se možným chybám } \\
\text { skórování. }\end{array}$ & 5 \\
\hline 2.3 .3 & $\begin{array}{l}\text { Pro interpretaci a vytváření zpráv: } \\
\text { Detailní doporučení týkající se interpretace různých skórů, chápání normativních měr a zacházení se vztahy } \\
\text { mezi rủznými škálami, s množstvím ilustrativních příkladů a př́ipadových studií. }\end{array}$ & 4 \\
\hline 2.3 .4 & $\begin{array}{l}\text { Pro poskytnutí zpětné vazby a debriefingu respondentům testu a dalším: } \\
\text { Detailní doporučení, jak prezentovat zpětnou vazbu uchazečům. }\end{array}$ & 1 \\
\hline 2.3 .5 & $\begin{array}{l}\text { Pro poskytování dobrých praktických témat týkajících se poctivosti a } \\
\text { zkreslení: } \\
\text { Uvedení detailních informací o studiích sexuálního a etnického zkreslení s relevantními varováními týkajícími } \\
\text { se používání a zobecňování validit. }\end{array}$ & 1 \\
\hline 2.3 .6 & $\begin{array}{l}\text { Omezení používání: } \\
\text { Jasné popisy, kdo by měl a kdo by neměl být vyšetřován spolu s dobře vysvětlenými odůvodněními těchto } \\
\text { omezení (např. typy nezpůsobilostí, požadované úrovně gramotnosti atd.). }\end{array}$ & 3 \\
\hline 2.3 .7 & $\begin{array}{l}\text { Reference a podpůrné materiály: } \\
\text { Detailní odkazy na relevantní podpůrnou akademickou literature a křížové odkazy na další příbuzné } \\
\text { materially týkající se diagnostických nástrojü. }\end{array}$ & 4 \\
\hline $\begin{array}{l}\text { Kval } \\
\text { (Tento }\end{array}$ & $\begin{array}{l}\text { Materiálů: } \\
\text { ový rating se získá použitím posouzení založeného na hodnotách ratingů pro položky } 2.4-2.8 \text { ) }\end{array}$ & 5 \\
\hline 2.4 & $\begin{array}{l}\text { Všeobecná kvalita materiálů testu } \\
\text { (testové brožury, odpověd'ové archy, testové objekty, software atd.): }\end{array}$ & 5 \\
\hline 2.5 & Kvalita lokální adaptace testu (pokud byl test přeložen a adaptován do místního jazyka): & 4 \\
\hline 2.6 & Snadnost, s jakou může respondent testu porozumět úkolu: & 5 \\
\hline 2.7 & $\begin{array}{l}\text { Snadnost, s jakou mohou být respondentem testu tvořeny reakce nebo } \\
\text { odpovědi: }\end{array}$ & 5 \\
\hline 2.8 & Kvalita položek: & 5 \\
\hline \multicolumn{3}{|c|}{$\begin{array}{l}\text { Recenzentovy komentáře týkající se dokumentace: } \\
\text { (komentáře principů, designu, vývoje testu a jeho přijatelnosti) }\end{array}$} \\
\hline \multicolumn{3}{|c|}{$\begin{array}{l}\text { CAS2 představuje na první pohled velice dobře vytvořenou baterii přátelskou k administrátorovi } \\
\text { i k probandovi. Manuály jsou přehledné, jasně strukturované a podávají zřejmé návody, jak test } \\
\text { administrovat a vyhodnocovat, popisují rozsáhle proces standardizace a normy, důkazy reliability a } \\
\text { validity testu. Bohužel však téměř úplně chybí část popisující vývoj testu, čtenár̆ se musí spokojit } \\
\text { pouze s konstatováním, že autoři se vypořádali s výtkami recenzentů k pưvodní verzi CAS, s detaily } \\
\text { nás již neobtěžují. Část týkající se interpretace testu je zpracována velice důkladně, bohužel však místo } \\
\text { návrhu postupu psaní výstupní zprávy nabízí jen jeden příklad takové zprávy. Instrukce pro } \\
\text { poskytnutí zpětné vazby téměř úplně chybí. }\end{array}$} \\
\hline
\end{tabular}


Během vývoje české verze testu se zjevně podařilo velice kvalitně přeložit praktické části testu potřebné $\mathrm{k}$ samotné administraci a vyhodnocování. $\mathrm{V}$ Technickém a interpretačním manuálu ovšem narážíte na místa, kde není jasné, zda se zrovna mluví o původní či české standardizaci. Autoři české verze testu uvádí, že to byl úmysl a že se obávali případné nepřehlednosti kapitol rozdělených na popis původní a české standardizace. Podle našeho názoru však právě spojením popisu původní a české standardizace nepřehlednost způsobili.

\section{Č́st 7: \\ Hodnocení norem, reliability a validity}

\section{Informace o normách nebo referenční skupině}

\begin{tabular}{|c|c|c|}
\hline 2.9 & Celková adekvátnost: & 4 \\
\hline 2.9 .1 & 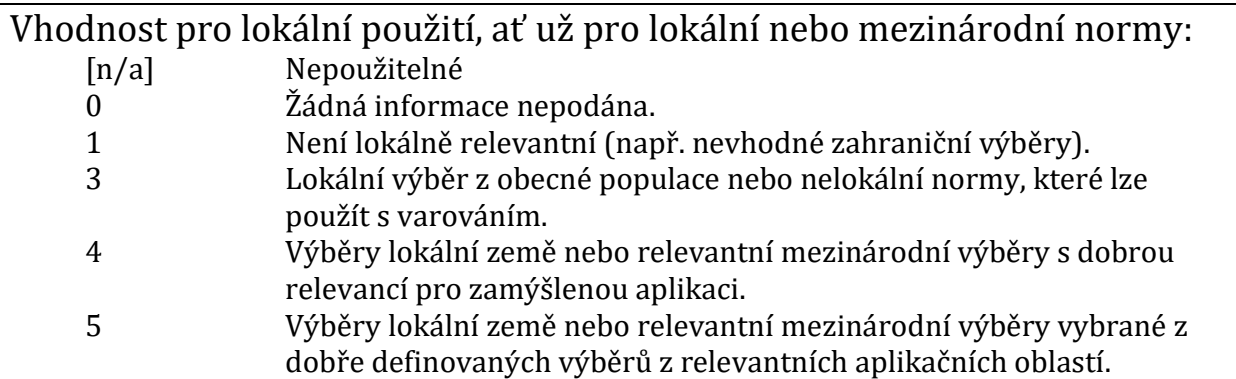 & 4 \\
\hline 2.9 .2 & $\begin{array}{ll}\begin{array}{l}\text { Vhodnost pro zamýšlené aplikace: } \\
{[\mathrm{n} / \mathrm{a}]}\end{array} & \begin{array}{l}\text { Nepoužitelné } \\
0\end{array} \\
1 & \text { Žádná informace nepodána. } \\
3 & \text { Norma nebo normy nejsou adekvátní pro zamýšlené aplikace. } \\
& \begin{array}{l}\text { Adekvátní normy pro obecnou populaci a/nebo rozmezí normativních } \\
\text { tabulek. }\end{array} \\
4 & \begin{array}{l}\text { Dobré rozmezí normativních tabulek. } \\
5\end{array} \\
& \begin{array}{l}\text { Vynikající rozmezí výběrově relevantních norem vztahujících se k věku } \\
\text { a pohlaví, s informacemi o dalších rozdílech v rámci skupin (např. } \\
\text { směs etnických skupin). }\end{array}\end{array}$ & 4 \\
\hline 2.9 .3 & 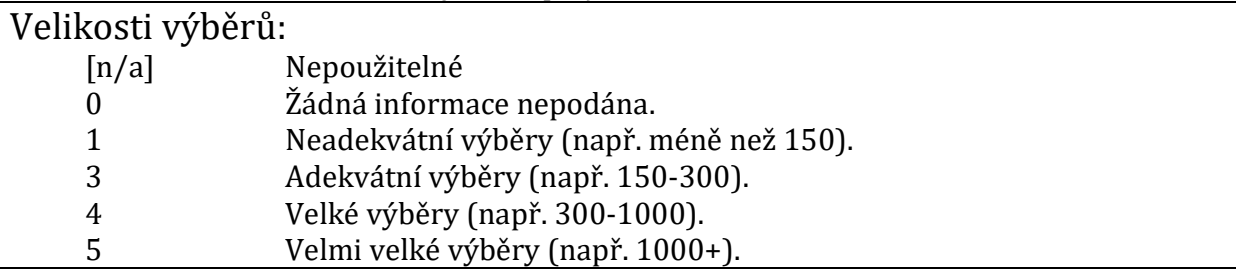 & 4 \\
\hline 2.9 .4 & $\begin{array}{cl}\text { Procedury použité při výběru souboru: } \\
\square & \text { Žádná informace neposkytnuta } \\
\square & \text { Reprezentativní populaci } \\
\square & \text { Nahodilá } \\
\square & \text { Náhodná }\end{array}$ & 3 \\
\hline
\end{tabular}


2.9.5 $\quad$ Kvalita informací poskytnutých o minoritní/chráněné skupině, rozdílech, vlivech věku, rodu atd.:

$\begin{array}{ll}\text { [n/a] } & \text { Nepoužitelné } \\ 0 & \text { Žádná informace nepodána. } \\ 1 & \text { Neadekvátní informace. } \\ 3 & \text { Adekvátní obecné informace s minimální analýzou. } \\ 4 & \text { Dobré popisy a analýzy skupin a rozdílů } \\ 5 & \text { Vynikající série analýz a diskuse o relevantních tématech vztahujících } \\ & \text { se k použití a interpretaci. }\end{array}$

2.9.6 Komentáře recenzentů k normám: Stručná zpráva o normách a jejich historii, včetně informací o doporučeních učiněných vydavatelem/autorem pro aktualizaci norem obvyklým způsobem.

V České republice byl proveden kvótní výběr vzorku $(\mathrm{N}=896)$ podle věku, pohlaví, velikosti místa bydliště, vzdělání rodičů a speciálních vzdělávacích potřeb probandů. Bohužel na úrovni vzdělávacích potřeb zůstal na hrubém rozlišení výskyt/nevýskyt. Také se nepodařilo zcela uspokojivě zajistit adekvátní zastoupení probandů s rodiči se základním vzděláním (ve vzorku 3,9\%, dle ČSÚ z 2014 8\%) a výučním listem (ve vzorku 26,6\%, dle ČSÚ z 2014 39\%). To může vést k podhodnocování výsledků vyšetřených osob. České normy také postrádají jakékoli zohlednění minorit, přičemž autoři lokální verze argumentují homogenitou populace ČR.

\section{Validita}

\begin{tabular}{|c|c|c|}
\hline 2.10 & $\begin{array}{l}\text { Celková adekvátnost: (Tento celkový rating se získá na základě posouzení hodnot ratingů } \\
\text { daných v položkách } 2.10 .1-2.10 .2 .4 \text {. Neprüměrujte pouze čísla, abyste získali celkový rating. } \\
\text { Obvykle bude roven bud' konstruktové validitě nebo validitě vztahující se ke kritériu, podle } \\
\text { toho, která z nich je vyšší.) }\end{array}$ & 3,5 \\
\hline 2.10 .1 & $\begin{array}{l}\text { Konstruktová validita - celková adekvátnost } \\
\text { (Tento celkový rating se získá na základě posouzení hodnot ratingů daných v položkách } \\
2.10 .1 .2-2.10 .1 .6 \text {. Neprumměrujte pouze čísla, abyste tento celkový rating získali.) }\end{array}$ & 4 \\
\hline 2.10 .1 .1 & $\begin{array}{cl}\text { Použité plány: (zatrhněte tolik, kolik je jich použitelných) } \\
\square \quad \text { Žádná informace nepodána } \\
\bigotimes \quad \text { Korelace s dalšími nástroji a výkonovými kritérii } \\
\square \quad \text { Vnitroškálový (korelace položky se zbytkem) } \\
\bigotimes \quad \text { Rozdíly mezi skupinami } \\
\square \quad \text { Matice mnoha rysů a mnoha metod (MTMM) } \\
\square \quad \text { Explorační faktorová analýza } \\
\bigotimes \quad \text { Konfirmační faktorová analýza } \\
\square \quad \text { Experimentální plány } \\
\square \quad \text { Jiné: }\end{array}$ & \\
\hline 2.10 .1 .2 & $\begin{array}{cl}\begin{array}{c}\text { Velikosti výběrů: } \\
0\end{array} & \text { Žádná informace neposkytnuta. } \\
1 & \text { Jedna neadekvátní studie (např. velikost výběru menší než 100). } \\
3 & \text { Jedna adekvátní studie (např. velikost výběru 100-200). } \\
4 & \text { Více než jedna adekvátní nebo velká studie. } \\
5 & \text { Dobrá série adekvátních až rozsáhlých studií. } \\
\end{array}$ & 4 \\
\hline 2.10 .1 .3 & $\begin{array}{cl}\text { Procedura výběru souboru: (vyberte jednu) } \\
\square \quad \text { Žadná informace neposkytnuta } \\
\square \quad \text { Reprezentativní vůči populaci [sumarizujte kritéria] } \\
\square \quad \text { Nahodilá } \\
\square \quad \text { Náhodná }\end{array}$ & \\
\hline 2.10 .1 .4 & $\begin{array}{cl}\text { Medián a rozsah korelací mezi testem a dalšími podobnými testy: } \\
0 & \text { Žádná informace neposkytnuta. } \\
1 & \text { Neadekvátní }(\mathrm{r}<0.55) . \\
3 & \text { Adekvátní }(0.55<\mathrm{r}<0.65) . \\
4 & \text { Dobrý }(0.65<\mathrm{r}<0.75) . \\
5 & \text { Vynikající }(\mathrm{r}>0.75) \\
\end{array}$ & 4 \\
\hline
\end{tabular}




\begin{tabular}{|c|c|c|c|}
\hline 2.10 .1 .5 & $\begin{array}{c}\text { Kvalita } \\
0 \\
1 \\
3 \\
4 \\
5\end{array}$ & $\begin{array}{l}\text { nástrojů jako kritérií nebo markerů: } \\
\text { Žádná informace neposkytnuta. } \\
\text { Poskytnuta neadekvátní informace. } \\
\text { Adekvátní kvalita. } \\
\text { Dobrá kvalita. } \\
\text { Vynikajíć kvalita s širokým rozsahem relevantních markerů pro } \\
\text { konvergentní a divergentní validizaci. } \\
\end{array}$ & 4 \\
\hline 2.10 .1 .6 & & $\begin{array}{l}\text { diferenciálního fungování položek (DIF): } \\
\text { A ] } \\
\text { Nepoužitelné } \\
\text { hodnocení kvality DIF analýzy }\end{array}$ & $\begin{array}{l}0 \\
\text { (v původní } \\
\text { verzi } 4 \text { ) }\end{array}$ \\
\hline 2.10 .2 & $\begin{array}{l}\text { Validi } \\
\text { (Tento ce } \\
2.11 .1-2\end{array}$ & $\begin{array}{l}\text { Vztahující se ke kritériu - celková adekvátnost } \\
\text { ový rating se získá na základě posouzení hodnot ratingů daných v položkách } \\
0.2 .4 \text {. Neprüměrujte pouze ćísla, abyste získali celkový rating.) }\end{array}$ & 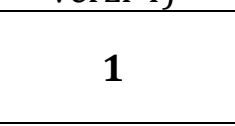 \\
\hline 2.10 .2 .1 & $\begin{array}{r}\text { Popis } 1 \\
\square \\
\square \\
\square\end{array}$ & $\begin{array}{l}\text { užitých kritérií a charakteristik populací: (zatrhněte tolik, kolik je pc } \\
\text { Souběžná } \\
\text { Prediktivní } \\
\text { Postdiktivní }\end{array}$ & \\
\hline 2.10 .2 .2 & $\begin{array}{c}\text { Velikc } \\
0 \\
1 \\
3 \\
4 \\
5 \\
\end{array}$ & $\begin{array}{l}\text { ti výběrů: } \\
\text { Žádná informace neposkytnuta. } \\
\text { Jedna neadekvátní studie (např. velikost výběru menší než 100). } \\
\text { Jedna adekvátní studie (např. velikost výběru 100-200). } \\
\text { Jedna velká nebo vice než jedna adekvátně rozsáhlá studie. } \\
\text { Dobrá série adekvátních až rozsáhlých studií. }\end{array}$ & 4 \\
\hline 2.10 .2 .3 & $\begin{array}{r}\text { Proced } \\
\square \\
\square \\
\square \\
\square\end{array}$ & $\begin{array}{l}\text { ra výběru souboru: } \\
\text { Žádná informace neposkytnuta } \\
\text { Účelná nebo reprezentativní } \\
\text { Nahodilá } \\
\text { Náhodná }\end{array}$ & \\
\hline 2.10.2.4 & \begin{tabular}{|c} 
Mediár \\
0 \\
1 \\
3 \\
4 \\
5 \\
\end{tabular} & $\begin{array}{l}\text { a rozsah korelací mezi testem a kritérii: } \\
\text { Žádná informace neposkytnuta. } \\
\text { Neadekvátní (napřr. } \mathrm{r}<0.2 \text { ). } \\
\text { Adekvátní (např. } 0.2<\mathrm{r}<0.35 \text { ). } \\
\text { Dobrý (např. } 0.35<\mathrm{r}<0.50 \text { ). } \\
\text { Vynikající (např. } \mathrm{r}>0.50 \text { ) } \\
\end{array}$ & [n/a] \\
\hline \multicolumn{4}{|c|}{ 2.10.3 Komentáře recenzenta týkající se validity: } \\
\hline \multicolumn{4}{|c|}{$\begin{array}{l}\text { Česká adaptace metody vychází z výzkumů validity provedené na americké verzi testu. K nim } \\
\text { pak připojují dvě vlastní studie na malých vzorcích, které popíšeme níže. Konstruktovou } \\
\text { validitu původní autoři nejprve zkoumají srovnáním s původním testem CAS, zkrácenou verzí } \\
\text { CAS2: Brief, posuzovacími škálami CAS2: Rating Scale a řadou metod měřících příbuzné } \\
\text { konstrukty (WISC-IV, CTONI-2, PTONI, WJ-III, TOSCRF-2, GORT-5, CMAT, WRAT-4). Korelace } \\
\text { s příbuznými metodami jsou podle očekávání vysoké (CAS r }=0,88 \text {, CAS: Brief } r=0,8 \text {, CAS: } \\
\text { Rating Scale } r=0,75 \text { ) a i s dalšími metodami jsou velice uspokojivé. Českého čtenáře bude asi } \\
\text { nejvíce zajímat korelace s WISC-IV ( } \mathrm{r}=0,77) \text { a s WJ-III ( } \mathrm{r}=0,62) \text {. Korelační studie jsou ovšem } \\
\text { provedené na relativně malých vzorcích (např. u WISC-IV N = 35, u WJ-III N = 36) a jejich } \\
\text { platnost je navíc omezena i specifickými populacemi, které byly výzkumu podrobeny (např. } \\
\text { u WISC-IV i WJ-III se jednalo hlavně o děti s ADHD a poruchami chování). Je také nejasné, do } \\
\text { jaké míry jsou konstrukty měřené pomocí CAS2 př́buzné s konstrukty měřenými } \\
\text { srovnávanými testy. }\end{array}$} \\
\hline \multicolumn{4}{|c|}{$\begin{array}{l}\text { Poměrně silný důkaz validity testu však poskytuje hlubší analýza standardizačního souboru, } \\
\text { kde autoři původní verze testu hledají rozdíly mezi skupinami podle věku, genderu, rasy a } \\
\text { etnické příslušnosti. Rozdíly odpovídají očekávání, nap̌̌. výkon prakticky ve všech subtestech } \\
\text { koreluje pozitivně s věkem. Autoři dále zjistili, že např. probandi identifikovaní jako „nadaní } \\
\text { a talentovaní" mají významně vyšší průměrný celkový skór (o 11,8 bodů) a že probandi, } \\
\text { u nichž byl diagnostikován syndrom ADHD, získali nízké skóry ve škálách Pozornost } \\
\text { a Plánování. }\end{array}$} \\
\hline
\end{tabular}


Autoři původního testu také na standardizačním souboru provedli konfirmační faktorovou analýzu, kde zkoumali celkem 4 modely ve 4 věkových skupinách. Předpokládaný čtyřfaktorový model odpovídá pozorovaným datům nejlépe $\left(\chi^{2} / d f=2,1\right.$ až 3,2; $R M S E A=0,057$ až 0,102$)$. Jak ovšem správně poznamenává ve své recenzi McGill (2015), autoři v manuálu ve všech ostatních částech pracují s hierarchickým modelem, kdy by měla druhá Lurijova funkční jednotka v sobě zahrnovat simultánní a následné procesy, ten však konfirmační faktorovou analýzou vůbec netestují. Odchylují se od něj k jednoduchému čtyřfaktorovému modelu bez nějakého hlubšího komentáře. Také není jasné, jak se autoři testu vyrovnali s kritikou původní verze CAS Kranzlera a Keitha (1999), kteří pro standardizační data nalézají přiléhavější faktorové řešení odporující teorii PASS. To, že jejich kritika může být oprávněná, dokumentují skóry RMSEA, které jsou pod přijatelnou hodnotou 0,06 (Hu \& Bentler, 1999) pouze u čtyřfaktorového modelu testovaného na datech dětí ve věku 8-10 let.

Posledním argumentem původních autorů pro validitu metody je analýza provedená opět na standardizačním souboru. Autoři předpokládali, že probandi používající konkrétní strategie v subtestech Plánování (bud' pozorované administrátorem anebo zmíněné v inquiry) budou významně lépe skórovat ve škále Plánování. Tento předpoklad se potvrdil, ovšem výsledná velikost efektu byla zanedbatelná (Cohenovo $d=0,06$ až 0,19 ). Dokonce v subtestu Plánované spojení byl efekt opačný, než autoři předpokládali (Cohenovo $\underline{d}=-0,03$ ).

V ČR byly provedeny dvě malé validizační studie. V první z nich výzkumníci srovnávali dvojicí testů 20 probandů se specifickými poruchami učení. $10 \mathrm{z}$ nich testovali pomocí CAS2 a WISC-III a dalších 10 pomocí CAS2 a K-ABC. Zjistilo se, že metody spolu korelují (s WISC-III $r=0,51$; s K-ABC $r=0,68$; $p<0,05)$, ale podrobnější výsledky byly nejednoznačné. Další malá studie byla provedena na 12 dětech $\mathrm{s}$ hraničním intelektem a MR. I v této studii spolu CAS2 a WISC-III korelovaly $(\mathrm{r}=0,62 ; p<0,05)$. Vzhledem k nízkému počtu probandů se ovšem dají tyto studie nazývat spíše pilotními, což uznávají i autoři české standardizace, kteří volají po dalším relevantním výzkumu. Hodnocení validity se tak (podobně jako u reliability) do velké míry opírá o výzkumy týkající se anglické verze testu.

\section{Reliabilita}

\begin{tabular}{|c|c|c|}
\hline 2.11 & $\begin{array}{l}\text { Celková adekvátnost: } \\
\text { (Tento celkový rating se získá na základě posouzení hodnot ratingů daných v položkách 2.11.1-2.10.2.4. } \\
\text { Neprůměrujte pouze čísla, abyste získali celkový rating.) }\end{array}$ & 3,5 \\
\hline 2.11 .1$. & $\begin{array}{c}\text { Poskytnutá data týkající se reliability: (vyberte jednu možnost) } \\
\square \quad \text { Uveden pouze jeden koeficient reliability } \\
\square \quad \text { Uveden pouze jeden odhad standardní chyby měření } \\
\square \quad \text { Koeficienty reliability pro několik různých skupin } \\
\square \quad \text { Standardní chyba měření uvedená pro několik různých skupin }\end{array}$ & \\
\hline 2.11 .1 & Vnitřní konzistence: & \\
\hline 2.11.1.1 & $\begin{array}{cl}\text { Velikost výběru: } \\
0 & \text { Neposkytnuta žádná informace. } \\
1 & \text { Jedna neadekvátní studie (např. rozsah výběru menší než 100). } \\
3 & \text { Jedna adekvátní studie (např. rozsah výběru 100-200). } \\
4 & \text { Jedna rozsáhlá nebo vice než jedna adekvátně rozsáhlá studie. } \\
5 & \text { Dobrá série adekvátních až rozsáhlých studií. } \\
{[\mathrm{N} / \mathrm{A}]} & \text { Nepoužitelné. } \\
\end{array}$ & 4 \\
\hline
\end{tabular}


3.0 Hodnotící zpráva testu:

Tato část by měla obsahovat stručné, jasně obhájené posouzení nástroje/produktu. Mělo by popisovat jeho pro a proti a poskytnout určitá obecná doporučení týkající se toho, jak a kdy by se měl používat - spolu s varováními (kde jsou potřebná) týkajícími se případů, kde by se používat neměl.

V souladu se závěry zahraničních recenzentů (Acheson, 2017; Champ Morera, 2017; McGill, 2015) považujeme CAS2 za originální metodu, která je velice jednoduše administrovatelná a jež má kvalitně zpracované testové materiály. CAS2 oproti jiným dostupným testům kognitivních schopností nabízí ipsativní analýzu, tedy na statistice založenou identifikaci silných a slabých stránek probanda. Skóry testu mohou s určitou opatrností posloužit k identifikaci nadání či ověření hypotézy o mentální retardaci. Test neposkytuje zcela jasná vodítka pro diagnostiku všeho ostatního, co podle autorů diagnostikovat má (ADHD, poruchy učení, traumatické poranění mozku, vážné emoční poruchy). Analýzou jeho výsledků se může psycholog dobrat k zajímavým závěrům, které jeho diagnostické úvahy podstatně zpřesní. Jeho možné využití tedy spatřujeme jak v oblasti klinické, tak v oblasti školsky poradenské. Dokonce můžeme na základě výzkumu (Naglieri et al., 2006) spekulovat o tom, že výsledky CAS2 lépe korelují s akademickým úspěchem než výsledky WISC-III.

Původní důkazy validity a reliability na amerických vzorcích jsou přes jisté výhrady dostatečně přesvědčivé. Bohužel obdobně silné důkazy na českých vzorcích v materiálech naší verze chybí. Můžeme se domnívat, že vzhledem k typu položek testu se toho překladem příliš změnit na reliabilitě a validitě nemohlo, ovšem je to skutečně pouze domněnka, která si žádá další ověření. V USA vyšly rovněž materiály, které na základě výsledků CAS2 vytváří plán intervencí. Ty bohužel v české lokalizaci nenajdeme. Autoři české verze testu jsou si však vědomí těchto nedostatků, nabádají k dalšími výzkumu a spekulují nad překladem materiálů k intervencím.

\subsection{Závěry:}

Přes výše zmíněné nedostatky můžeme CAS2 doporučit s jistou opatrností k běžnému užívání, a to hlavně díky aktuálním českým normám vytvořeným na základě poměrně velkého standardizačního souboru. Je však nutné počítat s tím, že normy jsou pravděpodobně o něco „tvrdší" v důsledku nižšího zastoupení rodičů respondentů s nižším vzděláním. 


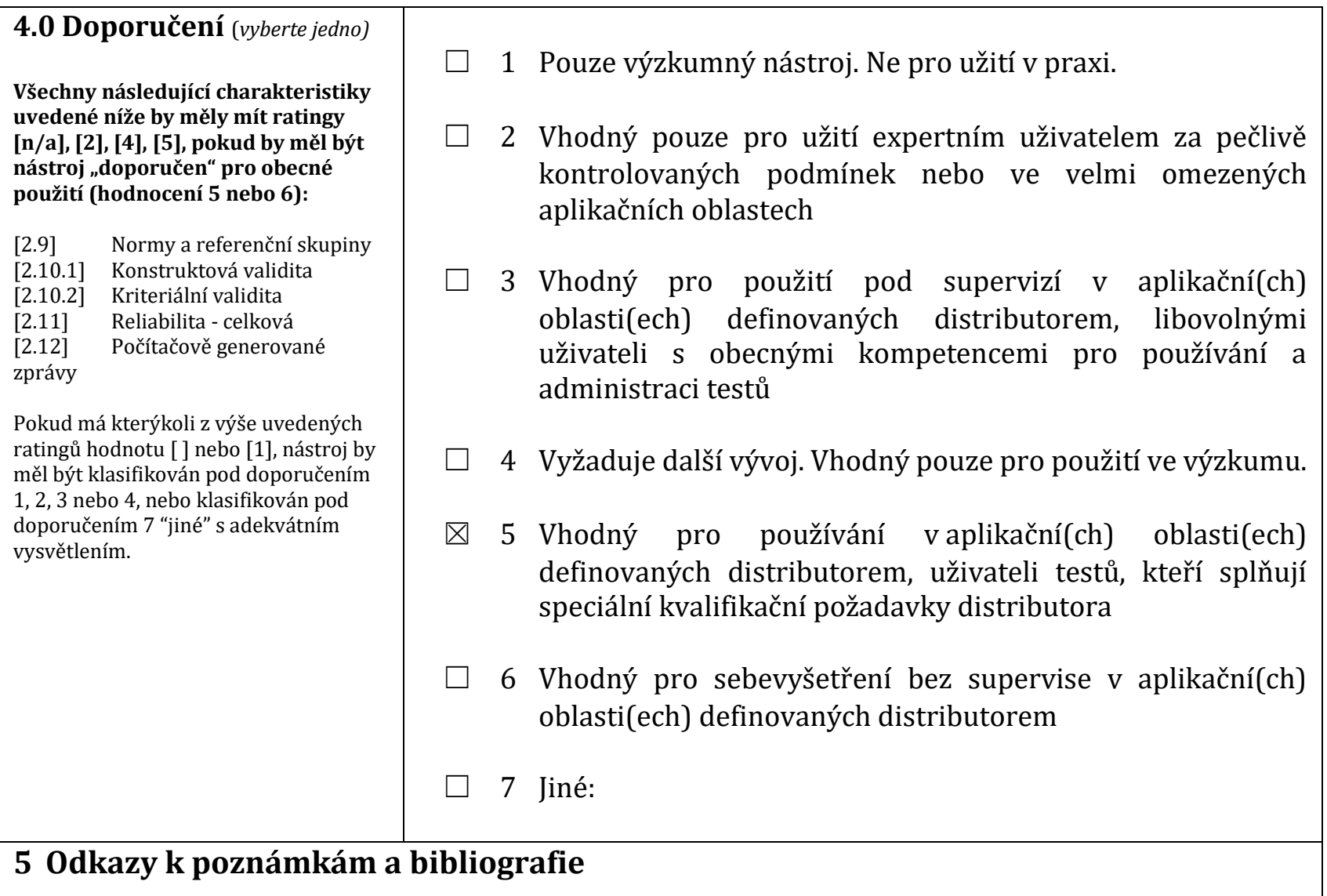

Acheson, S. K. (2017). Test review of Cognitive Assessment System-Second Edition. In J. F. Carlson, K. F. Geisinger, \& J. L. Jonson (Eds.), The twentieth mental measurements yearbook. Dostupné z http://marketplace.unl.edu/buros/

Champ Morera, C. A. (2017). Test review of Cognitive Assessment System-Second Edition. In J. F. Carlson, K. F. Geisinger, \& J. L. Jonson (Eds.), The twentieth mental measurements yearbook. Dostupné z http://marketplace.unl.edu/buros/

Das, J. P., Kirby, J. R., \& Naglieri, J. A. (1994). Assessment of cognitive processes: the PASS theory of intelligence. Boston: Allyn and Bacon.

Hu, L., \& Bentler, P. M. (1999). Cutoff criteria for fit indexes in covariance structure analysis: Conventional criteria versus new alternatives. Structural Equation Modeling: A Multidisciplinary Journal,6(1), 1-55. doi: 10.1080/10705519909540118

Ježek, S. (2010). Standardy pro užívání psychologických testů - nastal čas pro českou normu? Testfórum,1(1), 18-22. doi: 10.5817/TF2010-1-5

Kranzler, J. H., \& Keith, T. Z. (1999). Independent confirmatory factor analysis of the Cognitive Assessment System: What does the CAS measure? School Psychology Review, 28, 117-144.

Lurija, A. R. (1973). The working brain: an introduction to neuropsychology. New York, NY: Basic Books.

Mcgill, R. J. (2015). Test Review: Naglieri, J. A., Das, J. P., \& Goldstein, S. (2014). Cognitive Assessment System-Second Edition (2nd ed.). Austin, TX: Pro-Ed. Journal of Psychoeducational Assessment, 33(4), 375-380. 


Naglieri, J. A., Lauder, B. Y., Goldstein, S., \& Schwebech, A. (2006). WISC-III and CAS: Which Correlates
Higher with Achievement for a Clinical Sample? School Psychology Quarterly,21(1), 62-76. doi:
10.1521/scpq.2006.21.1.62
Propsyco. (2017a). CAS2. Dostupné 26.12. 2017,
z http://shop.propsyco.cz/product.php?id_product=27.
Propsyco. (2017b). Jak na to. Dostupné 26.12. 2017, z http://shop.propsyco.cz/cms.php?id_cms=7.
Měřené konstrukty:
Plánování, pozornost, následné procesy, simultánní procesy, celková škála kognitivních procesů,
exekutivní funkce s pracovní pamětí, exekutivní funkce bez pracovní paměti, pracovní pamét', verbální
obsah, neverbální obsah.

